\title{
Lise Öğrencilerinin Okula Aidiyet Duyguları ve Sosyal İyi Oluşları Üzerine Karma Bir Araştırma ${ }^{1}$
}

\author{
DOI: 10.26466/opus.517176 \\ * \\ Durmuș Ümmet ${ }^{*}-$ Selçuk Doğan ${ }^{* *}$ - Hatice Pınar Kemahli** \\ * Doç. Dr., Marmara Üniversitesi, Atatürk Eğitim Fakültesi, Kadıköy/İstanbul/Türkiye \\ E-Posta: dummet@marmara.edu.tr ORCID: 0000-0002-8318-9026 \\ ** Dr., University of Florida, Florida/ USA \\ E-Posta: selcukdogan78@gmail.com \\ ORCID: $\underline{0000-0002-0527-8453}$ \\ *** Araş. Gör., Düzce Üniversitesi, Eğitim Fakültesi, Düzce/Türkiye \\ E-Posta: haticepinarozdemir@gmail.com ORCID: $\underline{0000-0003-1324-3426}$
}

$\ddot{O} z$

Okula aidiyet duygusu, öğrencilerin okuldaki diğger kişilerden ne düzeyde onay aldığına, kendisine ne kadar saygı duyulduğuna, etkinliklere ne miktarda dahil edildiğine ve desteklendiğine dönük kişisel duyguların ifade etmektedir. Bu çalışmanın amacı lise öğrencilerinin okula aidiyet duygularının sosyal iyi oluşları bağlamında incelenmesidir. Araştırmada, nicel ve nitel araştırma yöntemlerinin beraber yürütüldüğ̈̈ karma yöntem kullanılmıştır. Nicel boyutta PISA 2015 verileri, nitel boyutta ise yarı yapılandırılmış görüşme formu ile görüşme tekniği kullanılmıştır. Nicel örneklem PISA 2015 araştırmasında ulaşılmış olan 5895 Türkiye'deki 15 yaş grubu lise öğrencisinden oluşmaktadır. Nitel çalışma grubu ise 12 ögrenciden oluşmaktadır. Verilerin istatistiksel analizlere uygunluğunu belirlemek için bir dizi hesaplamalar yapıldıktan sonra amaca göre parametrik ve non-parametrik analizler yapılmıştır. Araştırma bulguları incelendiğinde, nicel aşamada öğrencilerin okula aidiyetleri ile sosyal iyi oluşun aile ilişkileri, öğretmen ilişkileri ve aile desteği alt boyutları arasında anlaml, akran ilişkileri ile anlaml olmayan ilişkilere ulaşılmıştır. Nitel bulgularda ise nicel bulgularla örtüşen ve nicel bulguları destekleyici nitelikte sonuçlara ulaşılmıştır. Elde edilen bulgular bütünlük içinde tartışılarak öneriler getirilmiştir.

Anahtar Kelimeler: Okula aidiyet duygusu, Sosyal iyi oluş, Lise öğrencisi, Karma yöntem

\footnotetext{
${ }^{1}$ Bu araştırma Marmara Üniversitesi Bilimsel Araştırma Projeleri Birimi (BAPKO) tarafindan desteklenmiştir. (Proje No: EGT-A-070617-0411)
} 


\title{
A Mixed Study on High School Students' Sense of Belonging to School and Social Well-Being
}

\begin{abstract}
The sense of belonging to the school refers to the personal feelings of the students about how much approval they have from other people in the school, how much they are respected, how much they are included in the activities and supported. The aim of this study is to examine high school students' sense of belonging to school in terms of social well-being. In this study, the mixed methods research, which involves quantitative and qualitative research methods, was used. For quantitative method, PISA 2015 data and for qualitative method, semi-structured interview form was used. Quantitative sample is composed of 5895 high school students in the age group of 15 reached through PISA survey in 2015. The qualitative study group consists of 12 students. After a series of calculations were made to determine the suitability of the data for statistical analysis, parametric and non-parametric analyzes were performed. When the findings of the study are examined, it has been found that there is a meaningful relationship between the family relations, teacher relations, family support sub-dimensions and the school belonging together with social well-being of the students in the quantitative study, but not meaningful relations with peer relations. In qualitative findings, the results have been reached match and support the quantitative findings. The findings have been discussed coherently and suggestions have been made.
\end{abstract}

Keywords: A sense of belonging to school, Social well-being, High school student, Mixed method 


\section{Giriş}

Öğrencilerin akademik başarıları, tüm gelişim alanlarındaki görevlerinin yerine getirilebilmesi, daha geniş ifadeyle eğitim-öğretimin hedeflerine ulaşması öğrencilerin okula dair hissettikleri aidiyet duygusu ile yakından ilgilidir. Okula aidiyet duygusu, konuyla ilgili kişileri son zamanlarda daha çok odaklandığı bir kavramdır (Alkan, 2016). Okula aidiyet duygusu, öğrencilerin okuldaki diğer kişilerden ne düzeyde onay ald1ğına, kendisine ne kadar saygı duyulduğuna, etkinliklere ne miktarda dahil edildiğine ve desteklendiğine dönük kişisel duygularını ifade etmektedir. Bu bağlamda okula aidiyet akademik başarı ve performans, motivasyon ve öz yeterlilikle ilişkili olarak ele alınmaktadır (Goodenow ve Grady, 1993; Roeser, Midgley ve Urdan, 1996). Yapılan alan yazın incelemesi, okula aidiyet duygusunun hangi değişkenlerden etkilendiğini gösteren yeterli çalışmanın mevcut olmadığını göstermiştir. Bu ihtiyaçtan hareketle yapılan alan incelemesinde "sosyal iyi oluş" kavramı ile karşılaşılmıştır. Öğrencilerin akademik başarısı ve bu başarıyı etkileyen nedenler üzerine alanda bazı çalışmalar yapıldığı görülmüştür. Fakat son 10 yılda, sadece öğrencilerin akademik ya da bilişsel durumlarının değil, onların okuldaki sosyal iyi oluşlarının da önemli olduğu sıkça vurgulandığı görülmektedir. Kuramsal çalışmalar ve literatür taramaları, sosyal iyi oluşu öğretmen, akran ve aileyle ilgili olacak şekilde kavramsallaştırmaktadır (Borgonovi ve Pal, 2016). Bu konuda yapılan araştırmalar ise, sosyal iyi oluşun, öğrencilerin okula bağlılı̆̆ın etkileyen önemli bir faktör olduğuna işaret etmektedir (OECD, 2015). Yabancı kaynaklara bakıldığında, sosyal iyi oluşla ilgili kavramsallaştırma (Moore, Murphey ve Bandy, 2012) ve öğrencilerin kendi görüşleriyle ilgili (Rees ve Main, 2015) çalışmalar göze çarpmaktadır. Aynı zamanda, öğrencilerin iyi oluşlarının çeşitli eğitim çıtıları üzerindeki etkisi de incelenmiştir (Gutman ve Vorhaus, 2012). Fakat özellikle Türkiye'deki öğrenciler üzerine bu ve benzer alanda yapılan çalışmaların yok denecek kadar az oluşu dikkat çekmektedir. Özellikle ergenlik dönemine denk gelen 15 yaş, öğrencilerin iyi oluş durumlarını incelemek için önemlidir. Bu yaştaki öğrencilerin, vakitlerinin çoğunu okulda arkadaş ve öğretmenleriyle geçirdikleri bilinmektedir. Okula aidiyet, akran etkileşimleri ve öğretmenlerle olan ilişkileri bu dö- 
neme daha yoğun şekilde gelişmekte ve değişmektedir (Özdemir ve Sağkal, 2016). Bu ve benzeri faktörler, öğrencilerin gelecekteki meslek seçimini, kariyerindeki başarı durumunu ve toplumdaki rolünü etkilemesi açısından dikkat çekmektedir.

\section{İyi Oluş Kavramı}

Psikoloji başlangıçta insanların problemlerini çözmek için kişiliğin sağlıksız olan boyutlarına odaklanmışken, bilimsel gelişmelerle birlikte bu zemin terk edilmeye başlanmıştır (Şirin ve Ulaş, 2015). 20. Yüzyılın postmodern psikoloji ekolleri, insanların olumlu özelliklerinin keşfedilip, geliştirilmesi ve yaygınlaştırılmasını bir tedavi yöntemi olarak kabul edip, insanı bir bütün olarak daha iyi hissetmesinin altında yatan değişkenleri araştırma çabası içine girmişlerdir (Seligman, 2002). Bu amaçla iyi olmanın çeşitli tanımları yapılmış ve iyi olmayı etkileyen değişkenlere yönelik farklı görüşler öne sürülmüştür. Psikolojide mutluluk, öznel iyi oluş kavramıla ele alınırken, öznel iyi oluş ise bireylerin olumlu duygulanım, olumsuz duygulanım ve yaşam doyumu açısından kendilerini öznel olarak değerlendirmeleri anlamına gelmektedir (Deiner, 2001). Ryff (1989) ise öznel iyi oluşu, psikolojik iyi olma kavramıyla açıklamış (Akt. Akın, 2008), bireyin kendini kabul etmesi, bireysel gelişimine dair olumlu bakışı, aile, akran ve öğretmenleri gibi diğerleriyle nitelikli ilişkiler kurması, çevreyi yönlendirme de etkili tutumu, güçlü özerk karar verme özelliği ve olumlu yaşam amacının olması bakımından 6 boyutta ele almıştır (Akt. Arslan ve Sarıcaoğlı, 2013). Ayrıca; yaşam doyumu, aile yaşamından doyum sağlama, yaşam standardı ve fiziksel sağlık, eğitim, öz saygı ve sosyal gibi birçok değişkenle iyi olma arasında ilişki kurulmuştur (Akın, 2008).

\section{Ergenlik Döneminde İyi Oluş}

Ergenlik dönemi kimlik kazanımının oluşturulduğu, bireyin kendisi olmak ve kendisini diğerleriyle ilişki içerisinde tanımlamak arasında kurduğu psiko-sosyal dengeyle çeşitli kimlik statüleri kazandığı bir gelişim dönemidir (Demir, 2009). Bireysel gelişimin ve yapılanmanın en belirleyici döneminde olan gençlere ait (Dilmaç ve Seki, 2015) uluslararası ve 
ulusal öznel iyi oluş literatürü incelendiğinde, ergen iyi oluş literatürünün henüz gelişmeye başladığı görülmektedir (Deiner, 2001).

Alan yazın incelendiğinde, ergenlik döneminde iyi oluşun farklı bağlamlarda ve değişen boyutlarda ve içeriklerde bahsedildiği görülmüştür. Yapılan çalışmalara göre, ergenlerde iyi oluş cinsiyet, yaş, eğitim, çevreyle olan ilişkiler, amaçlı etkinliklere katılma, öz saygı, bağlanma ve ait olma, aile desteği, işlevsellik, olumlu gelecek beklentisi, özgüven ve kişilik özellikleri bağlamında ele alınmıştır (Eryılmaz, 2011; 2013; Yaycı, 2016). Ergenlerin en çok zaman geçirdiği ortam okullardır. Öğrenciler okullarda sosyalleşir, öğretmen ve okul personeliyle etkileşim halinde olur. Okullarda iyi oluşun tanımlarına bakıldığında, çok boyutlu olarak ele alındığı göze çarpmakta ve daha çok öznel iyi oluşla ilişkilendirildiği gözlemlenmektedir. Alan yazında, (OECD, 2015) tarafından için geliştirilen ve PISA (Programme for International Student Assessment) tarafindan uyarlanan beş ögeli iyi oluş çerçevesi, okulda iyi oluşu tanımlamak için en çok kullanılan, kuramsal temeli güçlü bir yapıdadır. Bu çerçevede öğrencilerin akademik performanslarının yanında okul içi ve dışında öğrencilerin kendi hayatlarına ilişkin neler düşündükleri de yer almaktadır. Borgonovi ve Pal (2016) bu çerçeveyi birbirinden farklı fakat ilişkili beş ögede tanımlamaktadır. Bunlar, 1) bilişsel, 2) psikolojik, 3) fiziksel, 4) sosyal ve 5) materyal (maddi) iyi oluş boyutlarıdır. Bu çalışma kapsamında, alan yazında ilgili çalışmaların az olduğu sosyal iyi oluş ele alınacaktır.

\section{Sosyal İyi Oluş}

Sosyal iyi oluş temelinde öğrencilerin sosyal hayatının kalitesini ve sosyal ilişkilerin miktarını tarif eder (Helliwell ve Putnam, 2004; Rath, Harter, ve Harter, 2010). Bu tanım öğrencilerin kendi aileleri, akranları ve öğretmenleriyle olan ilişkileri ve okuldaki sosyal hayatlarını nasıl algıladıkları kapsamaktadır (Pollard ve Lee, 2003). Sosyal iyi oluş kendi içinde beş boyuta ayrılmaktadır: 1) okula aidiyet duygusu, 2) öğrencilerin ailesiyle ilişkisi, 3) aile desteği, 4) öğrencilerin akranlarıyla ilişkisi ve 5) öğrencilerin öğretmeniyle ilişkisi. Her boyutla ilgili tanımlar kısa bir şekilde aşağıda verilmiştir. 


\section{Sosyal İyi Oluş Boyutları ve Tanımları}

\begin{tabular}{|l|l|}
\hline $\begin{array}{l}\text { Sosyal iyi oluş bo- } \\
\text { yutları }\end{array}$ & \multicolumn{1}{|c|}{ Tanımlar } \\
\hline $\begin{array}{l}\text { Okula aidiyet duy- } \\
\text { gusu }\end{array}$ & $\begin{array}{l}\text { Akranlar tarafından kabul ve beğenilme (sevilme), arka- } \\
\text { daşlarına bağlı hissetme ve bir topluluğa ait olma hissi (Ba- } \\
\text { umeister ve Leary, 1995) }\end{array}$ \\
\hline $\begin{array}{l}\text { Öğrencilerin ailesiyle } \\
\text { ilişkisi }\end{array}$ & Aileyle olan iletişim ve etkileşim \\
\hline Aile desteği & Ailelerin çocuklarıyla okulla ilgili konularda ilgilenmesi \\
\hline $\begin{array}{l}\text { Öğrencilerin akranla- } \\
\text { rılyla ilişkisi }\end{array}$ & $\begin{array}{l}\text { Arkadaşlı, arkadaşlık kurma ve iletişimde kalma durum- } \\
\text { ları (Bollmer, Milich, Harris, ve Maras, 2005) }\end{array}$ \\
\hline $\begin{array}{l}\text { Öğrencilerin öğretme- } \\
\text { niyle ilişkisi }\end{array}$ & Öğretmenler olan paylaşım ve iletişim, öğretmene tutum \\
\hline
\end{tabular}

Bilişsel ve akademik iyi oluş kadar önem verilmeyen, sosyal iyi oluş, okula aidiyet kavramı bağlamında, bu araştırmanın odak noktasını oluşturmaktadır. Öğrencilerin okuldaki sosyal iyi oluş durumlarıyla ilgili Türkiye'de yerel ya da uluslararası bir çalışmaya rastlanmamıştır. Eğitim alanına katkı sağlamak ve iyi oluşun öğrenciler için önemini vurgulamak adına daha çok bilimsel çalışmalara ihtiyaç duyulduğu açıktır. Bu çalışmanın, Türkiye'ye genellenebilir çıkarımlar sunması dolayısıyla hem eğiti politikacılarına hem de uygulayıcı olan öğretmen ve okul psikolojik danışmanlarına katkı sunacağı düşünülmektedir. Ayrıca, araştırmanın boyutlarıyla ilgili derinlemesine bilgi sunacak olması, sosyal iyi oluşun okullarda nasıl ele alınacağına ilişkin öneriler geliştirmesine yardımcı olacaktır. Bu nedenlerle, bu araştırmanın temel amacı, Türkiye genelinde 15 yaş öğrencilerdeki sosyal iyi oluşun boyutlarını incelemek ve bu boyutların okula aidiyet duygusuna etkilerini ortaya çıarmaktır. Bu amaca uygun olarak aşağıdaki alt amaçlar belirlenmiştir.

1. Öğrencilerin sosyal iyi oluşları ile okula aidiyet duyguları arasında anlamlı ilişkiler var mıdır?

2. Öğrencilerin sosyal iyi oluş ve okula aidiyetlerine dair deneyimleri ve algiları nasıldır?

3. Araştırmanın nicel bulguları ile nitel bulguları birbiriyle örtüşmekte midir? 


\section{Yöntem}

\section{Araștırmanın Modeli}

Bu çalışma karma araştırma yöntemlerinden açımlayıcı sıralı desen modeline göre planlanmıştır. Nitel ve nicel verilerin bir arada kullanıldığ 1 karma yöntem araştırmalarında açımlayıcı sıralı desen, araştırmacının nicel bir araştırmayla başladığı, ikinci aşamayla özel sonuçlar aradığı bir karma yöntem desenidir. İkinci aşamanın (nitel aşamanın) amac1; nicel veride ortaya çıkan yönelimleri ve ilişkileri derinlemesine açıklamaktır (Creswell, 2012). Bu çalışmada da nicel verilerin analizi sonucu elde edilen bulguları açıklamak ve derinleştirmek için nitel veriler kullanılmıştır.

Araştırmanın nicel kısmında, genel tarama modelinin bir alt türü olan ilişkisel tarama modeli kullanılmıştır. İlişkisel tarama, iki ya da daha fazla değişken arasındaki ilişkiyi belirlemek ve neden-sonuç ile ilgili ipuçları elde etmek amacıyla yapılan araştırma modelidir (Büyüköztürk, KılıçÇakmak, Akgün, Karadeniz ve Demirel, 2008). Bu araştırmanın nicel bölümü, PISA verilerinin ikincil analizi yapılarak ilerletilmiştir.

Araştırmanın ikinci aşaması olan nitel bölümünde araştırma sorularının yanıtları için ayrıntılı verilere ve derinlemesine analizlere ihtiyaç duyulmaktadır. Bu sebeple bireylerin bir olguya ilişkin yaşantılarını, algılarını ve buna yüklediği anlamları ortaya çıkarmayı amaçlayan çalışmalara uygun olan "fenomonoloji" deseni uygulanmıştır. Nicel kısım da ortaya çıkan model doğrultusunda ilgili değişkenlere dair bireylerin algıları, derinlemesine ve bütüncül şekilde ortaya konulmuştur (Yıldırım ve Şimşek, 2011).

\section{Çalışma Evreni ve Grubu}

PISA 2015 Türkiye uygulamasında 15 yaş grubu öğrenci evreni 1.324.089 olarak belirlenmiştir, fakat 925.366 öğrenci ulaşılabilir evren olarak ele alınmıştır. Çalışma Türkiye'de bilgisayar tabanlı olarak 61 il, 187 okuldan 5895 öğrencinin (2937 kız ve 2958 erkek) katılımıyla gerçekleşmiştir. PISA da örneklem tabakalı seçkisiz örnekleme yöntemiyle belirlenmiştir (Taş, Arıcı, Ozarkan, ve Özgürlük, 2016). Bu çalışmada, ilgili boyutlarda verisi olan tüm öğrenciler çalışmaya dahil edilmiştir. 
Araştırmanın nitel kısmında, nicel olarak analiz edilen verilerin detaylandırılması, anlamlandırılması ve derinlemesine analiz edilebilmesi için 15 yaş grubu öğrenciler içerisinden "amaçlı örneklem" çeşitlerinden biri olan "maksimum çeşitlilik" örneklem yöntemi ile 12 öğrenci seçilmiştir. Örneklem çeşitliliğinde, sosyoekonomik düzey ve cinsiyet değişkenleri dikkate alınmıştır. Patton'a (Akt. Şimşek ve Yıldırım, 2011) göre amaçlı örnekleme zengin bilgiye sahip olduğu düşünülen durumların derinlemesine çalışılmasına olanak vermektedir. Amaçlı (yargısal) örneklemede araştırmacı kimlerin seçileceği konusunda kendi yargısını kullanır ve araştırmanın amacına en uygun olanları örnekleme alır. Maksimum çeşitlilik örneklemde ise çalışılan konuyla ilgili deneyim sahibi olabilecek bireylerin çeşitliliğini maksimum derecede yansıtmak hedeflenir. Amaç, çeşitliliği sağlamak yoluyla evrene genelleme yapmak değil, çeşitlilik gösteren durumlar arasında ne tür ortaklıkların veya benzerliklerin var olduğunu bulmaktır.

\section{Verilerin Toplanması ve Analizi}

Araştırmanın nicel bölümünde, OECD tarafından 2015 yılında düzenlenen PISA 2015 çalışmasındaki Türkiye verilerinden yararlanılmıştır. Daha derinlemesine bilgi toplayabilmek için, aynı grubu temsil eden öğrencilerden görüşme yoluyla nitel veri toplanmıştır. Bu yönüyle, bu araştırmada nicel veriler hali hazırda bulunmakta; nitel verilerse, nicel verilerin analizi sonrasında toplanmıştır. Detaylar her iki bölüm için ayrı ayrı aşağıda açılanmiştır.

Araştırmanın nicel bölümünde, verilerin toplanması adımı, OECD tarafından 2015 yılında düzenlenen PISA 2015 çalışmasına dayanmaktadır. PISA 2015'te dörtlü likert ölçeği ile öğrencilerden sosyal bağlarına, bir başınalıklarına ve okul topluluğuna aidiyetlerine ilişkin duygularını almaya yönelik sorular ile veriler toplanmıştır. Toplanan veriler, sosyal iyi oluş kavramı altında birleştirilmiş ve beş farklı boyutta ele alınmıştır. Bu çalışmanın beş farklı değişkenini oluşturan her boyut farklı sayıda madde içermektedir.

1) Öğrencilerin ailesiyle ilişkisi: Bu boyut öğrencilerin ailesiyle olan ilişkisinin ne kadar etkin olduğunu iki maddeyle ölçmektedir. 
2) Aile desteği: $\mathrm{Bu}$ boyut öğrencilerin ailelerinden aldığı destek ve onlarla ne kadar ilgilendiğini ölçen dört maddeyi içermektedir.

3) Öğrencilerin akranlarıyla ilişkisi: Bu boyut öğrencilerin arkadaşlarıyla olan iletişimini ve etkinliklerini iki maddeyle ölçmektedir.

4) Öğrencilerin öğretmeniyle ilişkisi: Bu boyut altı madde kullanarak, öğrencilerin öğretmenlerinin tutumlarına karşı geliştirdikleri algıyı ölçmektedir.

5) Okula aidiyet duygusu: Bu boyut öğrencilerin okul topluluğuyla olan ilişkilerinin kalitesini izlemek için altı madde kullanmaktadir.

Bu çalışmada toplam 20 madde OECD tarafından, öğrenci iyi oluş kavramsal çerçevesine göre geliştirilmiştir. Bu çalışmada PISA'daki kuramsal temele sadık kalınarak maddelerin hepsi alınmıştır. Boyutların yapı geçerliğini test etmek için, çok düzeyli doğrulayıcı faktör analizi kullanılmış (DFA) ve her boyutun .724-.876 arasında faktör yüklerine sahip olduğu görülmüştür. Boyutların güvenirliği için, faktör yüklerinden yararlanılarak kompozit güvenirlik kat sayısı (Raykov, 2004) aile desteği için .856, okula aidiyet için .838 , ve öğretmen öğrenci ilişkisi için .770 olarak hesaplanmiştır.

Nitel verilerin toplanması ise, nitel araştırmada görüşme türleri arasında yer alan "yarı yapılandırılış görüşme" yoluyla sağlanmıştır (Creswell, 2012). Bu araştırmada nicel araştırma amaçlarından yola çıkılarak görüşme maddeleri yazılmış ve taslak form oluşturulmuştur. Veri toplama aracı olarak ise araştırmacılar tarafından geliştirilen "görüşme formu" biri okullarda çalışan psikolojik danışman, diğerleri psikolojik danışmanlık ve rehberlik anabilim dalı öğretim üyelerinden oluşan üç uzman görüşüne sunularak gerekli düzenlemeler yapılmış, 15 yaşında olan iki öğrenci ile pilot uygulama gerçekleştirilmiştir. Böylece görüşme formunun geçerlilik ve güvenirliliği sağlanmıştır.

Nitel veri toplama süreci, araştırmanın nicel boyutunun analizi sonucunda elde edilen veriler doğrultusunda belirlenen örneklem üzerinde, gönüllülük ilkesi de göz önünde bulundurularak seçilen 12 öğrenciyle yasal izin alındıktan sonra, yarı yapılandırılmış görüşmeler yapılmıştır. Görüşmelerde kayıtlar dijital ses kayıt cihazlarıyla kaydedilmiş ve herhangi bir aksama olasılığını göz önünde bulundurarak not alabilmek için gerekli hazırlıklar yapılmıştır. Ayrıca, her görüşmede araştırmacı, görüşmelerin 
sözel olmayan yönlerine ilişkin olarak notlar almış ve bu notları özellikle analiz ve yorumlama aşamalarında göz önünde bulundurmuştur. Görüşmeler 40-60 dakika arasında sürmüştür.

Araştırmanın nicel bölümü, birçok değişkenin karşılıklı ve karmaşık ilişkilerini incelemek amacıyla planlamıştır. Ayrıca, PISA verisi doğası gereği hiyerarşik bir yapıdır. Bu nedenle, nicel verilerin analizi için, çok düzeyli (multilevel) regresyon modeli koşulmuştur. Bu şekilde, hem iki aşamalı örneklemenin kümelerin bağımsızlığı ilkesi ihlal edilmemiş olacak, hem de boyutların ölçülmesindeki hata ve boyutların açıllanamayan varyanslarındaki ilişkiler gizil değişken olarak hesaba katılmış olmaktadır. $\mathrm{Bu}$ analizler için PISA tarafından verilen örneklem yükleri hesaba katılmıştır. Nicel verilerin analizi için, tüm bu gereksinimleri hesaba katabilen Mplus 7.4 yazılımı kullanılmıştır (Muthén ve Muthén, 1998-2012).

Nitel verilerin analizinde fenomonolojinin veri çözümleme basamakları dikkate alınmıştır. Araştırmanın görüşmeleri tamamlanıp, ses kayıtlarının yazıya dökümü gerçekleştirilmiştir. Yazıya döküm işlemi tamamlandıktan sonra tüm dökümler ele alınmış ve her birine sayfa numarası verilmiştir. Görüşme verileri ilk adımda tüm verilerin okunması, metinlere dair notlar alınması ve bir bütün halinde değerlendirilmesi şeklinde ele alınmıştır. Kodlamanın sağlıklı olabilmesi için veriler birkaç defa okunacak alınan notlar sıklıkla gözden geçirilmiştir. Görüşme verileri doğrultusunda notlar yardımıyla anlam grupları oluşturulmuş ve bunlar arasında ortak yönler belirlenmeye çalışılarak birbiriyle ilgili olanları aynı kategoride toplamak için temalar oluşturulmuştur. Oluşturulan temalar arasında anlam ilişkisi olanlar bir araya getirilmiştir. Temaların uygunluğu sürekli kontrol edilmiş ve gerekli görülen durumda düzenlemeler yapılmıştır. Son basamakta ise ortaya çıkan bulgular metinden alınan ifadeler ile okuyucuya sunulmuştur.

Araştırma başından sonuna kadar uzman görüşüne sunularak ilerlemiştir. Araştırmacılar görüşme formunu oluşturulurken sıkça meslektaş teyidine başvurmuştur. Veriler toplanırken geçerlik ve güvenirliği sağlamak adına katılımcıların etkilenmemesi için yönlendirilmemeleri konusuna özen gösterilmiştir. Güvenilirlik için iki ayrı araştırmacı karşılaştırmalı şekilde süreci götürmüştür. Araştırmacılar tarafından ayrı olarak hazırlanan bu kodlar üzerinden güvenilirlik çalışmaları gerçekleştirmiş ve 
sonrasında araştırmacılar beraber çalışarak ortak anlam grupları oluşturmuştur. Temalar araştırmanın amaçları çerçevesinde düzenlenmiştir. Bulgular raporlaştıılırken doğrudan aktarımlara sıkça yer verilmiştir.

\section{Bulgular}

Araştırmanın nicel ve nitel bulguları ayrı ayrı bölümlerde aşağıda verilmiştir.

\section{Nicel Bulgular}

Okula aidiyet duygusu ve sosyal iyi oluş boyutlarının araştırma kapsamındaki lise öğrencilerindeki mevcut durumlarını ortaya koyan betimsel istatistikler Tablo 1'de verilmiştir.

Tablo 1. Sosyal iyi oluş boyutlarına ilişkin betimsel istatistikler

\begin{tabular}{lccc}
\hline Değişkenler & $\begin{array}{c}\text { Min-Maks } \\
\text { Puan }\end{array}$ & $\begin{array}{c}\text { Ort. } \\
\overline{\mathrm{X}}\end{array}$ & $\begin{array}{c}\text { Std. } \\
\text { Sapma }\end{array}$ \\
\hline Okula aidiyet duygusu & $1-4$ & 2.19 & .72 \\
Öğrencilerin ailesiyle ilişkisi & $1-2$ & 1.18 & .34 \\
Aile desteği & $1-4$ & 3.24 & .70 \\
Öğrencilerin akranlarıyla ilişkisi & $1-2$ & 1.25 & .37 \\
Öğgrencilerin öğretmeniyle ilişkisi & $1-4$ & 1.72 & .67 \\
\hline
\end{tabular}

Tablo 2. Okula aidiyet duygusu sosyal iyi oluş boyutları arasındaki ilişkiler

\begin{tabular}{lccccc}
\hline Değgişkenler & $\mathbf{1}$ & $\mathbf{2}$ & $\mathbf{3}$ & $\mathbf{4}$ & $\mathbf{5}$ \\
\hline 1.Okula aidiyet duygusu & 1 & & & & \\
2.Öğrencilerin ailesiyle ilişkisi & $.044^{*}$ & 1 & & & \\
3.Aile desteği & $-.033^{*}$ & $-.175^{*}$ & 1 & & \\
4.Öğrencilerin akranlariyla ilişkisi & .001 & $.222^{*}$ & $-.040^{*}$ & 1 & \\
5.Öğrencilerin öğretmeniyle ilişkisi & $.047^{*}$ & $.061^{*}$ & $-.132^{*}$ & $-.068^{*}$ & 1 \\
\hline
\end{tabular}

Tablo 2 incelendiğinde; öğrencilerin okula aidiyet duyguları ile sosyal iyi oluşun aile ilişkileri ve öğretmen ilişkileri arasında pozitif yönde anlamlı ilişkiler olduğu görülmüştür $(\mathrm{p}<.05)$. Buna göre öğrencilerin aile ve öğretmen ilişkileri olumlu yönde arttıkça okula aidiyet duyguları da an- 
lamlı düzeyde artmaktadır. Diğer yandan öğrencilerin okula aidiyet duyguları ile sosyal iyi oluşun aile desteği boyutu arasında negatif yönde anlamlı bir ilişki olduğu belirlenmiştir ( $\mathrm{p}<.050)$. Bu bulguya göre öğrencilerin aile desteği artıkça okula aidiyet duyguları azalmaktadır. Son olarak, öğrencilerin okula aidiyet duyguları ile akran ilişkileri arasında anlamlı bir ilişki olmadığı görülmüştür.

Tablo 3. Sosyal iyi oluş boyutlarının okula aidiyet duygusuna etkisi

\begin{tabular}{lcccc}
\hline & \multicolumn{4}{c}{ Okula Aidiyet Duygusu } \\
\cline { 2 - 5 } Yordayıcı Değişken & $\boldsymbol{b}$ & $\begin{array}{c}\text { Std. } \\
\text { Sapma }\end{array}$ & $\mathcal{\beta}$ & $\boldsymbol{p}$ \\
\hline Öğrencilerin ailesiyle ilişkisi & .089 & .031 & .041 & $.005^{*}$ \\
Aile desteği & -.030 & .015 & -.028 & .051 \\
Öğrencilerin akranlarıyla ilişkisi & -.002 & .028 & -001 & .946 \\
Öğrencilerin öğretmeniyle ilişkisi & .044 & .014 & .040 & $.002^{*}$ \\
\hline
\end{tabular}

Not: $b$ standart olmayan etki katsayısın; $\beta$ ise standart etki katsayısını ifade eder. $R 2=\% 1$

Tablo 3'e göre, sosyal iyi oluşun aile ilişkileri ve öğretmen ilişkileri boyutlarının öğrencilerin okula aidiyetleri üzerinde istatistiksel olarak anlamlı etkisinin olduğu gülmüştür. Ancak sosyal iyi oluşun aile desteği ve akran ilişkileri boyutlarının okula aidiyetlerine olan etkilerinin istatistiksel olarak anlamsız olduğu görülmektedir. Tüm alt boyutlar bir arada okula aidiyet duygusu puanlarının yaklaşık \%1'ini açıklamaktadır. Öğrencilerin ailesiyle ilişkisindeki artış okula aidiyet duygusunun artışını etkilemektedir. Aynı şekilde, öğrencilerin öğretmenleriyle ilişkisi, onların okula aidiyet duygularının artmasında etkilidir. Ancak aile desteği ve akran ilişkileri okula aidiyette anlamlı etkiye sahip değildir.

\section{Nitel Bulgular}

PISA verilerinin ikincil analizinin yapıldığı nicel aşama sonucundaki bulguların derinlemesine incelenmesi ve özel sonuçların ortaya çıkarılması amacıyla nitel aşamaya geçilmiştir. Bu araştırmada nitel aşamanın amacl, nicel veride ortaya çıkan ilişkileri araştırma grubunun görüşleri üzerinden açıklamak ve ayrıntılandırmaktır. Çalışma grubundaki katılımcılardan elde edilen verilerin analizi sonucunda kişisel rehberlik, öğretim süreci, iletişim biçimi, davranış kontrolü ana temaları elde edilmiştir. Her bir ana 
tema alt temalardan meydana gelmekte ve bunlar ise farklı kodları içermektedir. Ortaya çıkan ana temalar ve onlara bağlı alt temalar ve kodlar tablo 2 'de sunulmuştur.

Tablo 4. Nitel bulgulara dayalı ortaya çıkan temalar, alt temalar ve kodlar

\begin{tabular}{|c|c|c|}
\hline Ana Temalar & Alt Temalar & Kodlar \\
\hline \multirow{2}{*}{$\begin{array}{l}\text { Kişisel Rehber- } \\
\text { lik }\end{array}$} & $\begin{array}{l}\text { Psikolojik Des- } \\
\text { tek }\end{array}$ & $\begin{array}{l}\text { Öğrenci sorunlarına duyarlılık, özgüveni } \\
\text { geliştiren görevler verme, motive etme, ha- } \\
\text { talara karşı tolerans gösterme, yaşam dene- } \\
\text { yimleri sunma }\end{array}$ \\
\hline & Sosyal Destek & $\begin{array}{l}\text { Arkadaşlık ilişkilerini kolaylaştırma, kurslar } \\
\text { ve grup etkinliklerine katılımı sağlama, ar- } \\
\text { kadaşlık ilişkisi yapılandırmada yardım, ak- } \\
\text { ran zorbalığını fark etme }\end{array}$ \\
\hline \multirow[t]{2}{*}{ Ö̈̆retim Süreci } & $\begin{array}{l}\text { Yöntem ve Tek- } \\
\text { nikler }\end{array}$ & $\begin{array}{l}\text { Farklı yöntem ve teknikler kullanma, dersi } \\
\text { akıcı ve keyifli hale getirme, öğrenci seviye- } \\
\text { sini dikkate alma, }\end{array}$ \\
\hline & Sınıf Yönetimi & Süreyi etkili kullanma, disiplini sağlama \\
\hline \multirow[t]{2}{*}{ İletişim Biçimi } & $\begin{array}{l}\text { Olumlu Yakla- } \\
\text { şım }\end{array}$ & $\begin{array}{l}\text { Samimiyet ve güler yüz gösterme, eşitlik be- } \\
\text { lirten tutum, saygılı, nazik gibi değerlere } \\
\text { dayalı konuşma biçimi }\end{array}$ \\
\hline & $\begin{array}{l}\text { Olumsuz Yakla- } \\
\text { şım }\end{array}$ & $\begin{array}{l}\text { Hakaret ve şiddet, öğrenciler arasında ay- } \\
\text { rımcılık, kuşaklararası kıyaslama }\end{array}$ \\
\hline \multirow{2}{*}{$\begin{array}{l}\text { Davranış Kont- } \\
\text { rolü }\end{array}$} & $\begin{array}{l}\text { Akademik Ba- } \\
\text { şarı Baskısı }\end{array}$ & $\begin{array}{l}\text { Dış kontrol odağı, aşırı beklenti, yoğun ilgi, } \\
\text { olumsuz iletişim biçimi }\end{array}$ \\
\hline & $\begin{array}{l}\text { Akademik Ba- } \\
\text { şarı Desteği }\end{array}$ & $\begin{array}{l}\text { İç kontrol odağı, sosyal etkinliklere yer } \\
\text { verme, duygusal destek ve anlayış, ölçülü } \\
\text { ilgi, etkili iletişim }\end{array}$ \\
\hline
\end{tabular}

\section{Öğrenciler, öğretmenlerin tutum ve davranışlarını okula aidiyet bağla- mında nasıl değerlendirmektedirler?}

Araştırmanın nitel aşamasının alt amacı, PISA verilerinin ikincil analizi yapılması sonucunda ortaya çıkan istatistiksel sonuçlara göre belirlenmiştir. Araştırmanın nicel sonuçları incelendiğinde, öğrencilerin okula aidiyet duyguları ile öğrenci-öğretmen ilişkisi arasında anlamlı ve pozitif bir ilişki olduğu, öğretmen-öğrenci ilişkisinin öğrencideki okula aidiyet duygusu 
üzerinde anlamlı bir etkiye sahip olduğu anlaşılmıştır. Ortaya çıkan bu sonuç dikkate alınarak öğrencilerle görüşmeler yapılmış, görüşmelerde katılımcılara öğretmen davranışları ile ilgili algıları ve deneyimleri sorulmuştur. Bu sorulara verilen cevaplar üzerinden öğretmenlerin hangi tutumu ve davranışlarının öğrencilerdeki okula aidiyet duygusunu etkilediğine dair öğrenci görüşleri incelenmiştir. Bu araştırmada çalışma grubundaki öğrenciler belirlenirken okula ait olma duygusunun ifade ettiği anlam PISA literatürüne uygun olarak anlatılmış, gönüllü öğrencilerin seçiminde bu duyguların yaşanma oranı bir kriter olarak belirlenmemiştir. Katılımcılar arasında okula ait hissettiğini, kendini okulda iyi hissettiğini söyleyen öğrenciler olduğu gibi yalnızlık duygusunu daha fazla yaşadığını, kendini yabancıymış gibi hissettiğini belirten öğrenciler de bulunmaktadır. Katılımcılar yaşadıkları duygu durumları bağlamında öğretmen-öğrenci ilişkilerini anlamlandırmış ve deneyimlerini paylaşmışlardır. Çalışma grubundaki katılımcılardan elde edilen verilerin analizi sonucunda kişisel rehberlik, öğretim süreci ve iletişim biçimi ana temaları elde edilmiştir. Bu bölümde katılımcıların duygu, düşünce ve deneyimlerinin özünü anlamak amacıyla her tema doğrudan alıntılarla desteklenmiştir.

\section{Kişisel Rehberlik}

Öğrencilerin eğitim ve öğretim gördükleri ortamlar, onların aile yaşamından sonra zamanlarını en fazla geçirdiği kurumlardır. Dolayısıyla öğrenciler kişisel özellikleri, psikolojik problemleri ve duygu durumları gibi tüm yönlerini okul yaşamlarına yansımaktadırlar. Bu sebeple eğitim kurumlarında eğitim ve öğretim faaliyetlerinin yanı sıra, öğrenciye yönelik çeşitli hizmet alanlarına da ihtiyaç duyulmuştur. Öğrencinin kişisel, duygusal ve sosyal özellikleri konusunda kendini keşfetmesi, sorun olarak algıladığı durumları ele alması ve yaşadığı psikolojik problemler konusunda destek sunulması kişisel rehberlik faaliyetleri kapsamı altında değerlendirilmektedir. Bu desteğin öğrencilere her ne kadar bir uzman tarafından sunulması gerekiyor olsa da diğer öğretmenlere de bu konuda görevler düştüğü katılımcıların görüşlerinden anlaşılmaktadır. Öğrenci görüşmeleri sonucunda ortaya çıkan veriler analiz edildiğinde, öğretmenle- 
rin öğrencilerle ilgilenmesi, onların sorunlarını dinlemesi, arkadaşlık ilişkileri kurmayı kolaylaştırması, öğrencileri motive etmesi gibi davranışlarının, öğrencilerin okula aidiyet/bağlanma [p2] duygularını etkilediğini belirtmişlerdir. Bu kodlar psikolojik destek ve sosyal destek alt teması altında iki kategoriye ayrıldıktan sonra kişisel rehberlik ana teması altında birleştirilmiştir. Bu doğrultuda geliştirilen alt temalarda öğrencilerin düşüncelerine yer verilmiştir.

Psikolojik destek. Bu alt tema öğrenci sorunlarına duyarlılı, özgüveni geliştiren görevler verme, motive etme, hatalara karşı tölerans gösterme, yaşam deneyimleri sunma kodlarından oluşmaktadır. Psikolojik destek alt teması altındaki öğrenci sorunlarına duyarlılık, yaşam deneyimleri sunma ve motive etme kodları, katılımcıların anlatımlarında oldukça sık rastlanan olgular arasında yer almaktadır. Okula ait olduğunu hisseden öğrenciler de okula bağlığının zayıf olduğunu düşünenler de, bu duygu durumlarının, öğretmenlerin onlara gösterdiği ilgi ve destekle ilişkili olduğuna dair düşüncelerini ifade etmiş ve yaşantılarını paylaşmışlardır. Katılımcıların ilgili görüşleri aşağıda sunulmuştur.

"Hep ders değil de kişisel hayat ile ilgili de konuşsalar örnekler verseler... Bu okulda da Ayşe Hoca çok ilgileniyor....Anlamlı konuştukları zaman çok dikkatimi çekiyor... İşte öğ̈̈t veriyor, kendini anlatıyor falan böyle."(Burcu).

"Öncelikle dertleri dinlemelerine..."(Akif).

"Ben olsam kendisi ile arkadaş olurum. Diyelim ben matematik hocasiyım tamam mi...giderim muhabbet ederim. Sorununun sorarım, bir derdi var mı?" (Hülya).

"Yakın konuşsunlar halimizi sorsunlar o kadar güzel ki dersler de onların anılarını dinlemek. İnsan bir şeyler öğreniyor. Daha hayattan konuşmak. Hem bilgilendiriyor onlarm anıları..."(Zeynep).

"Diğer Hocam beni tanıdı̆̆ iç̧in hal ve hareketleri mi olgunlukla karşılayabiliyordu. Bu ise beni tanımadığı için kızıyordu" (Murat).

"Bazı hocalar da seviyorum çünkü beni çok gazliyor. Mesela Metin hoca var diyor ki sinıftaki en zeki öğrencisi sensin. Senin 
yapabileceğine inanıyorum diyor, özel olarak konuşuyor. Çok seviyorum onu. Öyle söylediği için çalışasım geliyor. Eve gelip ders çalışıyorum."(Mustafa).

"Benim çok istediğim bir şey mesela bir öğretmen gelse benimle konuşmak istese... Ona görevler veririm simı içerisinde, derse kaldırmaya çalışırım, kendi istemese de yavaştan yavaştan onu zorlamayacak şekilde."(Nisa).

"Bir tane hocam vardı... Bir derdimiz olunca ona giderdik. Çünkü dertlerimizi dinliyor ve önemsiyor."(Mert).

Sosyal destek. Öğrenciler ile yapılan görüşmelerde kendini okula ait hissetme duygusunun, öğretmenin onlara gösterdiği sosyal destek ile ilgisi olduğu anlaşılmıştır. Verilerin analizi sırasında okula bağlanmalarına veya okulda yalnız hissetmelerine sebep olan öğretmen davranışlarına dair sorulan sorulara verilen cevapların, akranlarıyla olan ilişkileri odağında cevaplandırıldığı anlaşılmıştır. Öğrenciler tarafından verilen cevaplar incelendiğinde arkadaşlık ilişkilerini kolaylaştırma, kurslar ve grup etkinliklerine katılımı sağlama, arkadaşlık ilişkisi yapılandırmada yardım, akran zorbalığın fark etme kodlarının ortaya çıtı̆̆ görülmüştür. Öğrencilerin ifadelerinden anlaşıldığı üzere, akranlar arasındaki ilişki öğretmenlerin sağlayabileceği sosyal destek ile güçlenebildiği gibi; bu konudaki ilgisizlikte olumsuz etkiye sebep olabilmektedir. Katılımcıların altısı çevresiyle kurduğu ilişkilerde öğretmenlerine ihtiyaç duyduklarını aşağıdaki ifadeleriyle dile getirmişlerdir.

"Bazı erkek arkadaşlarımız bize kötü davranıyordu, özellikle ben köyden geliyorum diye böyle dalga geçiyorlar arkadaşlarım. Ya ben de bunu öğretmenlere çok söylemedim. öğrenciyiz ya her şeyi şikayet ediyorlar diye hiç ciddiye alamazdık, o çocuklara hiçbir şey yapmıyorlardı, disiplin cezası falan.... Acaba gerçekten öyle bir şey var mi diye bile ilgilenmezlerdi."(Nisa).

"Öğrenci mi alırım, dışarıya huzurlu bir yere götürürüm. Orada onunla güzelce konuşurum bir iki saat bütün dertlerini dinlerim. Ona zaman ayırırım. Onunla bir şeyler yaparım onu sosyal yaşama alıştırmaya çalışırım.... Arkadaşlarıyla arasımı iyi yapmaya çalışırım...küsünce barıştırırım..."(Mert). 
“Çünkü ben de ilkokulda bunları çok yaşıyordum. Hocam çok yardımcı oldu hani sürekli oyunları oynarken beni çă̆ırdı yanına, 'Hadi sen de gel katıl' ben yine çekinir gidemezdim ama. Sonra arkadaşlarımla yanıma gelince ben de açılmaya başladım. Ben olsam şimdi sını içerisinde onun da diğer öğrencilere katılmasını sağlarım. Onlarla birlikte aktiviteler yapmasını projelere katılmasını să̆larm." (Figen).

"Ben okulda kendimi çok yalnızım, fikirler öğretseler nasıl arkadaşlık kuracă̆ımız konusunda... Bir tane öğretmenim vardı tek oturduğumda yanıma birini koyardı."(Emre).

"Ben olsam onu çalışkan öğrencilerin yanına oturturdum..."(Mustafa).

\section{Öğretim Süreci}

Öğrenciler ile yapılan görüşmelerin analizi sonucunda öğretim süreci ana teması elde edilmiştir. Öğretim, öğrenciye eğitim hedeflerini kazandırmak için uygulanan bütün süreci ifade etmektedir. Öğretim süreci içerisinde programlar, teknik ve yöntemler, sınıf yönetimi gibi öğrenme öğretme faaliyetleri bulunmaktadır. Yapılan görüşmelerde, öğrencilerin okula ait hissetme duygusunu etkileyen öğretmen davranışları sorulduğunda, öğretmenlerin sınıf yönetimi ile öğretim yöntem ve tekniklerini kullanma konusundaki farklılıklarının öğrenciler tarafından dile getirildiği görülmüştür. Öğrencilerin öğretim sürecini belirten ifadeleri yöntemteknikler ve sınıf yönetimi olmak üzere iki alt tema içerisinde kümelenmiştir.

Yöntem ve teknikler. Öğretim yöntemi ve teknikleri öğrencinin nitelikli bir eğitim almasında öğretmenlerin dikkat etmesi gereken hususlardan biridir. Öğretim yöntem ve teknikleri öğrencinin özellikleri, dersin amaçları gibi birçok faktöre göre öğretmen tarafından belirlenmektedir. Bu yöntem ve tekniklerin seçimindeki amaç eğitim öğretim hedeflerine en kısa yoldan ve en iyi şekilde ulaşabilmektir. Bu araştırmanın bulguları doğrultusunda öğretmenler tarafından öğrencilere uygulanan öğretim yöntem ve tekniklerinin, öğrenci-öğretmen ilişkisinin bir parçası olduğu görülmüştür. Öğrencilerin ifadeleri analiz edildiğinde farklı yöntem ve teknikleri kul- 
lanma, dersi akıcı ve keyifli hale getirme, öğrenci seviyesini dikkate alma kodlarının yöntem ve teknikler alt teması içerisinde kümelendiği anlaşılıştır. Öğretmenlerin farklı öğretim yöntemleri kullanması ve öğrencilerin seviyelerini dikkate alarak dersi sürdürmesi, dersi tüm öğrenciler açısından daha anlaşılır hale getirmektedir. Bu durum katılımcıların odağını öğretim yöntemlerine çekmektedir. Ayrıca öğretmenin dersi daha keyifli ve akıcı bir şekilde sunması gerektiğinin bütün öğrenciler tarafından dile getirildiği görülmüştür. Bu alt temayı oluşturan alıntılardan bazılarına aşağıda yer verilmiştir:

“...Dersi akıcı geçiren öğretmenler. Dersi eğlenceli geçirenler... O kişinin aklını bilerek anlatması daha iyi olur bence, görsellerle anlatması..."(Burcu).

"İşledikleri ders mesela çok sıkıcı oluyor. Bizde dinlemiyoruz doğal olarak.... Çok sıkıcı ders işliyorlar öyle gibi. Bu bize okuldan soğutuyor."(Murat).

"Ben olsam hobilerini sorarım, hoşlandıkları şeyleri dersi ona göre anlatmaya çalışırım." (Mert).

"O kadar çok ders görüyoruz ki, bence çok zorlamaları gerekmiyor yavaş yavaş. Birazcık kolaylaştırsalar daha iyi olur yardımcı olsalar. Zor olunca yapamıyoruz çalışma isteğimiz gidiyor" (Semanur).

"Dersleri çok sıktıklarında okula gelmek istemiyoruz... Bir tane hocam vardl, o da simıfa gelir konuyu öyle dümdüz anlatır giderdi hiç konuşmazdl, başka bir şey yapmazdl, dinlemezdi. Onun dersine bile gitmek istemezdim." (Mert).

"Bence kesinlikle çok etkililer, çünkü bazen öyle dersler oluyor ki zamanın geçmemesini çok istiyoruz bazen matematik dersinde. Bizim hocamız var çok eğlenceli oluyor. Bazı soruları da kolay soruyor. Insan bu derslerde istekli oluyor." (Zeynep).

Sınıf yönetimi. Öğrenciler, öğretmenlerle kurdukları ilişkide okula bağl1lıklarını etkileyen öğretim süreci faktörlerinden bir diğeri olarak, sınıf yönetimini dile getirmişlerdir. Eğitim ortamının verimli bir şekle dönüşebilmesinin en önemli etkenlerinden biri etkili sınıf yönetimidir. Ders süresinin etkili kullanımı, sınıf içi kuralları belirleyip uygulayabilmesi, nitelikli öğrenci-öğretmen iletişimi gibi faktörler sınıf yönetimini oluşturmaktadır. 
Katılımcıların ifadeleri incelendiğinde öğrenci-öğretmen iletişimi farklı bir ana tema olarak öne çıktığı için bu alt tema süreyi etkili kullanma ve disiplini să̆lama kodlarının kümelenmesinden oluşmaktadır. Katılımcıların ifadeleri, sınıf yönetimi alt teması altındaki ders süresinin etkili kullanımına ve sınıf içerisinde disiplini sağlamaya yönelik ifadelerinin birkaçı aşağıda sunulmuştur.

"Şey şu yönde şey yapıyorlar. Kırk dakika boyunca ders. Çok sıkıcı oluyor. Bizde dinlemiyoruz doğal olarak. Sonra da derste gürültüler, konuşmalar, sesler gibi. Bu kez de hiçbir şey anlamıyoruz....ben olsam on dakikasında öğrenci ile sohbet ederdim."(Büşra).

"Derste tamamiyla anlatmasinlar. Kırk dakikanin hepsi ders olmasin. Bikıyoruz."(Figen).

"Derste bazen ara versinler, bir şeyler anlatsinlar, kendi anularından, şarkı olabilir, fikra, daha eğlenceli oluyor. Sıkılmıyoruz" (Emre).

"Bazı öğretmenlerimiz boş zaman geçiriyor, dersi kaynatıyorlar arkadaşlar öyle geçiyor ders. Verimsiz işte. Boşuna geldim okula diyorum. (Hülya).

\section{İletişim Biçimi}

Eğitim-öğretim sisteminde nitelikli bir eğitimci olabilmek için iletişim sürecini çok iyi kullanmak gerekmektedir. Çünkü eğitim bir etkileşim sürecidir. İletişim ise bu etkileşimin önemli bir yönünü oluşturmaktadır. Öğretmenler konuşma biçimi, öğrenciye yaklaşımı, jest ve mimikleri ile öğrenciye mesajlar vermekte ve onlarda yeni duygular ve tutumlar oluşmasına sebep olmaktadır. Öğrencinin çevreye karşı verdiği geri bildirim çoğunlukla iletilen mesajların niteliğine göre değişmektedir. Araştırma bulguları analiz edildiğinde, olumsuz yaklaşımlar karşısında katılımcıların okula aidiyet duygusunun azaldığı, olumlu yaklaşımlar karşısında ise fazlalaştığı anlaşılmıştır. Katılımcılardan edinilen veriler doğrultusunda iletişim biçimi ana teması ve ona bağlı olarak olumlu yaklaşım ve olumsuz yaklaşım alt temaları oluşturulmuştur. 
Olumlu yaklaşım. Eğitim ve öğretim kurumlarında öğretmenler, öğrencileri ile sürekli etkileşim içerisinde bulunmaktadırlar. Sınıf içerisinde ve s1nıf dışında devam eden bu iletişim hem öğrencilerin öğrenme yaşantılarını etkilemekte hem de çevreye karşı tutumlarını yapılandırmaktadır. Öğretmenlerin olumlu ve olumsuz olarak gruplandığ tepkilerinin (Cüceloğlu, 2001) iletişim sürecinde önemli bir yer tuttuğu katılımcların görüşlerinden anlaşılmaktadır. Katılımcılara göre öğretmenlerin dostça davranmaları, öğrenciye karşı samimi ve güler yüzlü olmaları, nazik ve kibar konuşmaları okula bağlanmaları açısından gerekli yaklaşımlardır. Bu sebeple samimiyet ve güler yüz gösterme, eşitlik belirten tutum, saygll, nazik gibi değerlere dayalı konuşma biçimi kodları olumlu yaklaşım alt teması altında birleştirilmiş, katılımcıların görüşleri ile desteklenmiştir.

“Öğretmenlerim Çok etkili. Güzel konuşsalar, dersleri sevdirmeye çalışsalar... bir tane hocam vard ... bizimle oturuyordu konuşuyordu, gülüyordu bizimle." (Mert).

"Biraz dost gibi arkadaş gibi daha samimi konuşmalı davranmalı" (Akif).

"Daha kibar davranabilirler. Bazı öğretmenler... Biraz argo kelimeler kullanabiliyor. Onları kullanmamalı öğretmenler. Biraz daha yumuşak konuşmalı"(Burcu).

"Güler yüzlü olsa bize yardımcı olsa. Daha sıcakkanlı olmaları., ilgilenmeleri bizimle... Öğrenciye biraz daha arkadaşça yaklaşmaları. Öğrenciye yukarıdan bakmamaları" (Büşra).

"Öğrenciyiz diye küçük görüyorlar hiç ciddiye almıyorlar" (Nisa).

Olumsuz yaklaşım. Yüzyıllardır öğretim sürecinde başrolü oynayan öğretmenler, öğrenci ile iletişiminde her zaman olumlu yaklaşımlar sergilememektedirler. Öğrenciyi azarlama, onlara hakaret etme, bağırma, şiddet gibi yaklaşımlar ve yanlış cezalandırma yöntemleri eğitim ortamlarında iletişim çatışmalarına, öğrencide istenmeyen davranışlara yol açmaktadır. Katılımcıların öğretmenlerin tutumlarına dair ifadeleri hakaret ve şiddet kodu ile kavramsallaştırılmış, bu yaklaşımların öğrenciyi okula yabancılaştırdığı anlaşılmıştır. Ayrıca öğretmenlerin tüm öğrencilere eşit mua- 
mele etmemesi, objektif davranmaması ve kendi öğrencilik dönemiyle öğrencilerin yaşamını sürekli olarak kıyaslaması katılımcıların şikâyet ettiği diğer bir konu olarak ortaya çıkmaktadır. Katılımcılar bu tür yaklaşımların onların okula aidiyet hissini olumsuz olarak etkilediğini belirtmiş, ifadeleri ise öğrenciler arasında ayrımcılık, kuşaklararası kıyaslama kodları ile olumsuz yaklaşım alt teması altında birleştirilmiştir. Katılımcıların ifadelerinden birkaçı aşağıda sunulmuştur.

"Hoca benibütün sınıfın içinde rezil etti. Bağırmıştı, çağırmıştı. Haftalarca o Hoca'dan çok uzak durmuştum. Çok üzülmüştüm... Bence bir hocanın tavrı öğrencinin okul hayatını o kadar çok etkiliyor ki. Geçenlerde yine oldu, ben haksızlğ̆l kaldıramayan bir insanım. Okulda kart oynamak yasak Ama erkekler arkada kart oynuyorlar. Ben de çok yorgundum uyuyorum yani başımı koymuşum hoca bana kızdı. Onlara değil bana bağırıyor. Nasıl adaletsizlik bu ya! İyi de ders işlendiği düşünmüyorum. Benim de başım çok ağrnyor yatıyorum. Sonra ben gittim Müdür Yardımcısına anlattım. Ağlamaya başladım çok üzüldüm. Çok etkiledi beni, hocaya kinle bakıyordum. Ters ters cevaplar veriyordum hıncımı almak için."(Hülya).

"Bir tane de hocamız vardı işte sinıfta sürekli bir tane kıza odaklanmıştı kız arkadaşımıza. Sürekli her etkinlikte o yapıyordu her şeyi. Bu da diğer arkadaşları üzüyordu yani ayrımollı yapıyordu"(Murat).

"Öğretmenler çok sinirli öyle olmamalı... sinıf ortasında azarlama salar... Özellikle yaşlı öğretmenleri hiç seomiyorum yeni öğretmenler daha anlayışlı. Yaşl öğretmenler sürekli kendi yaşama ile bizi kıyasliyor kendi dönemi ile. Bizim zamanımızda söyle olurdu böyle olurdu diyorlar ama artık onları zamanı değil."(Mustafa).

"O hoca kızların saçını çekiyor, bıkmıştık artık, nefret ettik dersinden" (Emre). 


\section{Öğrenciler, ebeveynlerinin tutum ve davranışlarını okula aidiyet bağ- lamında nasıl değerlendirmektedirler?}

PISA verilerinin ikincil analizi yapılması sonucunda ortaya çıkan diğer bir istatistiksel sonuç incelendiğinde, öğrencilerin okula aidiyet duyguları ile öğrenci-ebeveyn ilişkisi arasında anlamlı ve pozitif bir ilişki bulunmuştur. Ortaya çıkan bu sonuç dikkate alınarak öğrencilerle görüşmeler yapılmış, görüşmelerde katılımcılara ailelerin davranışları ile ilgili algıları ve deneyimleri sorulmuştur. Bu sorulara verilen cevaplar üzerinden ebeveynlerin hangi tutumu ve davranışlarının öğrencilerdeki okula aidiyet duygusunu etkilediğine dair öğrenci görüşleri incelenmiştir. Katılımcılar yaşadıkları duygu durum bağlamında ebeveyn-öğrenci ilişkilerini anlamlandırmış ve deneyimlerini paylaşmışlardır. Çalışma grubundaki katılımcılardan elde edilen verilerin analizi sonucunda, davranış kontrolü ana teması, bu ana temaya bağlı olarak akademik başarı baskısı ve akademik başarı desteği olmak üzere iki alt tema elde edilmiştir. Bu bölümde temalarla ilgili olarak katılımcların duygu, düşünce ve deneyimlerinin özünü anlamak amacıyla, her tema doğrudan alıntılarla desteklenmiştir.

\section{Davranış Kontrolü}

Birbirlerine biyolojik ve duygusal bağ ile bağlanan aile, üyelere ait sorumlulukların yerine getirilmesi ve belirlenen kuralların sürdürülmesinde aile içi davranış kontrolü işlevini kullanmaktadır. Aile yaşam döngüsüne bağlı olarak aile yaşamında çeşitli süreçler yaşanmakta ve konular gündeme gelmektedir. Bu süreçlerden biri çocukların okul dönemi ve ona bağlı olarak ortaya çıkan çocuklarının akademik başarısı konusudur. Ebeveynler çocuklarının okul yaşamı boyunca başarılı olmasını istemekte ve bu beklentilerinin gerçekleşmesine yönelik çocuklarına karşı çeşitli disiplin yöntemleri ve denetim biçimleri sergilemektedirler. Yapılan görüşmeler sonucunda akademik başarı konusunda algılanan bu davranış kontrolü biçimlerinin katılımcılar tarafından dile getirildiği görülmüş ve davranış kontrolü ana teması belirlenmiştir. Analizlerde öğrencilerin ifade ettiği davranış kontrolü biçimlerinin bir kısmının baskı olarak; bir kısmının ise destek olarak algılandığı fark edilmiş ve akademik başarı baskısı ile aka- 
demik başarı desteği alt temaları oluşturulmuştur. Temalarla ilgili olarak katılımciların duygu, düşünce ve deneyimlerinin özünü anlamak amacıyla her tema doğrudan alıntılarla desteklenmiştir.

Akademik Başarı Baskısı. Öğrencilerin okula aidiyet duygularının ebeveynlerin hangi tutum ve davranışlarından etkilendiğine dair öğrenci algılarının incelendiği araştırmada, öğrencilerin aileleriyle ilişkisinde ebeveynlerine ait bazı tutum ve davranışları baskı olarak algıladığı anlaşılmıştır. Akademik başarı baskısı bazı ebeveynlerin çocukların daha iyi eğitim alabilmesi için bilinçli olarak ya da bilinçsizce yaptığı davranışlar ve uyguladığı yöntemler sonucunda ortaya çıkmaktadır (Kapıkıran, 2016). Öğrencilerin ifadelerine bağlı olarak oluşturulan akademik başarı baskısı alt tema'sının, nicel aşamaya ait istatistiksel sonuçlarda ortaya çıan negatif ilişkiyi açıkladığ1 düşünülmektedir. Dış kontrol odağ̆, aşırı beklenti, yoğun ilgi, olumsuz iletişim biçimi kodlarının birleşmesiyle oluşan alt temaya ait katılımcıların görüşlerinden bir kaçı aşağıda bulunmaktadır.

"Ben herkes daha yüksek notlar alırım, ama onlar derler ki daha daha yüksek olsun en yüksek olsun. Yüksek not alyyorum, birçok dersten, ama birinden alamadığında hemen kızıyorlar, arka planda ne kadar çalıştı̆̆ımın farkında değiller. Sonuca bakıyorlar... Ben çaba gösteriyorum"(Mert).

"Ailem sürekli yüksek not almamı istiyor. Sürekli psikolojik baskı altında hissediyorum. Bu da düşük almamı sağhıyor. Çok baskı altında hissediyorum. Yani artık korkar oldum düşük alırsam ne olur, annemlere söylersem ne olur. Anlatmaya korkuyorum bizimkilere." (Nisa).

"Onlar söyleyince benim hiç çalışasım gelmiyor, annem sürekli çalış diyor, ama bu bana berbat hissettiriyor. Sürekli baskı oluşuyor üstümde sinir oluyorum. Çünkü ben bir şeyi kendim istemedikçe yapmiyorum."(Mustafa).

"Sürekli ders çalıs diyor. Hal ve hareketlerine dikkat et diyor, rahatsız oluyorum ama yine de ders yapmıyorum."(Büşra).

"Ailem çok etkili. Çok aşırı şekilde sıkıştırmaları ya da sormaları biraz soğutuyor okuldan... Ailem biraz azar demeyeyim de ses yükselmesi oluyor, o zaman işte okuldan soğuyorum."(Burcu). 
"Söylesinler evet ama sürekli sürekli değil, biraz daha az ilgilenseler derslerimle daha iyi olur"(Murat)

Akademik Başarı Desteği. Öğrencilerle yapılan görüşmelerde, akademik başarı için yapılması gereken etkinliklerin, yerine getirilmesi gereken yükümlülüklerin ebeveynler tarafından merak edilmesinin ve takip edilmesinin olağan bir durum olarak karşılandığı görülmüştür. Katılımcıların ifadelerinden ortaya çıkan verilere göre, nicel aşamadaki öğrencilerin okula aidiyet duygusu ile öğrenci-ebeveyn ilişkisini pozitif ve anlamlı bir ilişki olması sonucunun, ebeveyn davranışlarının yoğunluğuna ve niteliğine bağlı olduğu anlaşılmıştır. Analizler sonucunda görülmektedir ki katılımcılar, akademik başarının yükselmesine yönelik ebeveynlerin sergiledikleri birçok davranışı olumlu olarak niteleyip destek olarak değerlendirmişlerdir. Bu doğrultuda iç kontrol odağı, sosyal etkinliklere yer verme, duygusal destek ve anlayış, ölçülü ilgi, etkili iletişim kodlarının kümelenmesiyle birlikte akademik başarı desteği alt teması oluşturulmuştur. Katılımc1ların davranışlarına dair dikkat çeken görüşleri aşağıda verilmiştir.

"Mesela ben zorunlu çalıştığım zaman pek bir şey anlamıyorum. Ama kendi isteğimle çalıştığımda gayet anlıyorum. Ben olsam, ilk başta çok fazla sıkmazdım ama yine de sorardım, okula gider."(Akif).

"Ben olsam çocuğuma hiç baskı yapmam hiç ders çalış falan. Stnav zaman geldiğinde hatırlatırım yeter, gerisini kendi düşünsün. Ama hiç ilgilenmezlerse de bu sefer kendimizi çok saları, ergenlik falan."(Murat).

"Mesela Babam git diyor, derslerine çalış ama eğlenceni de yap ama dozunda yap abartma diyor. Bir ara ailem çok baskı yapıyordu böyle çalış, ben bayağı stres oluyordum böyle hani sürekli ders ders. Artık böyle psikolojim bozulmuştu. Yavaş yavaş bunun onlar bunu bana bıraktılar günde bir saat çalış iki saat çalıs demeye başladılar. Onlar da artık anladı gün boyunca okuldayım eve gelince de sürekli ders çalışmak bayağı yorucu oluyor. Okula bağlayan şey sadece ders değil ki, hatta hiç bir öğrenci dersi okula ya bağlamaz. Aktiviteler, kurslar, bir takımda olmak bunlar da insanı okula bağlar."(Semanur). 
“Gezmeye götürsünler beni hafta sonu farklı bir şeyler yapalım. Eğer çok merak ediyorlarsa beni dışar çıkarsınlar bir yemek yiyelim ya da bir kafeye götürsünler orada güzelce konuşsunlar okulun nasıl gidiyor. Arada bir böyle sorabilirler ama bask yapmasınlar."(Zeynep).

“Okuyup da iş kazanma konusunda kendi aramızda bayağı konuştuk ailemle, beni etkiledi. Her gün benimle düzenli olarak konuşmalarl, okulu sermem konusunda, günlük yaşamdan falan. Kalbimi kırmadan konuşmaya çalışmaları da önemli."(Figen).

\section{Tartışma ve Öneriler}

PISA verilerinin ikincil analizinin yapıldığı nicel aşama sonucunda bulguların derinlemesine incelenmesi ve özel sonuçların ortaya çıkarılması amacıyla nitel aşamaya geçilmiştir. Araştırmanın nicel sonuçları incelendiğinde, öğrencilerin okula aidiyet duyguları ile öğrenci-öğretmen ilişkisi arasında anlamlı ve pozitif bir ilişki olduğu, öğrenci-öğretmen ilişkisinin, öğrencilerin okula aidiyet duygularını pozitif yönde etkilediği anlaşılmıştır. Ortaya çıkan bu sonuç dikkate alınarak öğrencilerle görüşmeler yapılmış, görüşmelerde katılımcılara öğretmen davranışları ile ilgili algıları ve deneyimleri sorulmuştur. Bu sorulara verilen cevaplar üzerinden öğretmenlerin hangi tutumu ve davranışlarının öğrencilerdeki okula aidiyet duygusunu etkilediğine dair öğrenci görüşleri incelenmiş ve derinlemesine bilgi edinilmiştir. Çalışma grubundaki katılımcılardan elde edilen verilerin analizi sonucunda kişisel rehberlik, öğretim süreci ve iletişim biçimi ana temaları elde edilmiştir.

Öğrenci görüşmeleri sonucunda ortaya çıkan veriler analiz edildiğinde, öğretmenlerin öğrencilerle ilgilenmesi, onların sorunlarını dinlemesi, arkadaşlık ilişkileri kurmayı kolaylaştırması, öğrencileri motive etmesi gibi davranışlarının, öğrencilerin okula aidiyet/bağlanma duyguların etkilediğini belirtmişlerdir. Bu kodlar psikolojik destek ve sosyal destek alt teması altında iki kategoriye ayrıldıktan sonra kişisel rehberlik ana teması altında birleştirilmiştir. Okula ait olduğunu hisseden öğrenciler de okula bağlığının zayıf olduğunu düşünenler de, bu duygu durumlarının, öğretmenlerin onlara gösterdiği ilgi ve destekle ilişkili olduğuna dair dü- 
şüncelerini ifade etmiş ve yaşantılarını paylaşmışlardır. Öğrencinin kişisel, duygusal ve sosyal özellikleri konusunda kendini keşfetmesi, sorun olarak algıladığı durumları ele alması ve yaşadığı psikolojik problemler konusunda destek sunulması kişisel rehberlik faaliyetleri kapsamı altında değerlendirilmektedir. Okulun bir üyesi olarak değerli olduğunu düşünmeyi okula ait olma duygusunun temeli olduğunu ifade eden araştırmacılar, bu kavramı öğretmen öğrenci ilişkisi ile bağlantılı olarak görmüşlerdir (Juvonen, 2006). Yapılan araştırmalarda öğretmen ve öğrenciler arasındaki ilişki nitelikli bir şekilde devam ettiğinde öğrencilerin okula aidiyet duygularının geliştiği ve okula bağlandıkları görülmüştür (St-Amand, Girard ve Smith, 2017; Can, 2014; Cremmers ve Kyriakides, 2008). Dilekmen (2008) tarafından etkili bir ilişki kurmada kullandığı öğretmen davranışlarının ne olduğuna dair literatür taraması yaptığı araştırmasında öğrencilerin sorunlarıyla ilgilenme, gelişimlerini destekleme, onları motive etme, duygularını anlama, özgüvenini destekleme, iş birliğine dayalı bir ortam hazırlama ve olumlu bir çevre kurma konusunda yardım etme gibi tutum ve davranışları sıralamıştır. Yine Erden (1998) tarafından yapılan bir araştırmada, başarılı bir öğretmende bulunması gerekli nitelikler incelenmiş ve kişisel nitelikler içerisinde hoşgörülü, sabırlı, cesaretlendirici ve destekleyici olma gibi özelliklerin ön plana çıktığı görülmüştür. Cerit'in (2008) Öğretmen kavramı ile ilgili metaforlara ilişkin öğrenci, öğretmen ve yöneticilerin görüşlerinin incelediği araştırmasında öğrencilerin öğretmenler için danışman, koç, anne-baba, rehber gibi kavramlar kullandığı görülmüştür. Yapılan diğer araştırmalar incelendiğinde, öğrencilerin sorunlarryla ilgilenme, rehberlik yapma, sosyal faaliyetler konusunda teşvik etme, gelişimleri konusunda destekleme, ideal davranış modelleri ve yaşam deneyimleri sunma gibi öğretmenlerin psikolojik ve sosyal desteğinin öğrenci öğretmen ilişkisi içerisinde önemli bir etken olduğu anlaşılmıştır (Çakmak ve Aktan, 2016; Erden, Aytaç ve Altunçekiç, 2014; Fidan, Budan, Yüksel, Kasapoğlu ve Yamaç, 2012; Finn, 1989; Gordon and Burch 2003). İlgili literatür incelendiğinde ortaya çıan sonuçların rehberlik ana teması altındaki psikolojik ve sosyal destek alt temalarına ait öğrenci sorunlarına duyarlılık, özgüveni geliştiren görevler verme, motive etme, hatalara karşı tolerans gösterme, yaşam deneyimleri sunma, arkadaşlı ilişkilerini kolaylaştırma, kurslar ve grup etkinliklerine katılımı sağlama, arkadaşlık ilişkisi yapılandırmada yardım, akran zorbalı̆̆ını fark etme kodlarıyla örtüştüğü görülmektedir. 
Öğrenciler ile yapılan görüşmelerin analizi sonucunda ikinci kategori olarak öğretim süreci ana teması elde edilmiştir. Yapılan görüşmelerde, öğrencilerin okula ait hissetme duygusunu etkileyen öğretmen davranışları sorulduğunda, öğretmenlerin sınıf yönetimi ile öğretim yöntem ve tekniklerini kullanma konusundaki farklılıklarının öğrenciler tarafından dile getirildiği görülmüştür. Öğrencilerin öğretim sürecini belirten ifadeleri yöntem-teknikler ve sımı yönetimi olmak üzere iki alt tema içerisinde kümelenmiştir. Öğretim yöntemi ve teknikleri öğrencinin nitelikli bir eğitim almasinda öğretmenlerin dikkat etmesi gereken hususlardan biridir. Ders süresinin etkili kullanımı ve sınıf içi kuralları belirleyip uygulayabilmesi gibi faktörler sınıf yönetimini oluştururken, bireysel farklılıkları dikkate alarak dersi anlatma, dersi daha akıcı ve keyifli hale getirebilme ve farklı yöntem ve teknikleri kullanma gibi faktörler ise öğretim yöntem ve tekniklerinin içerisinde değerlendirilmiştir. Clemson ve Craft (1981) tarafından yapılan araştırmada öğretmenin kullandığı yöntem ve tekniklerin nitelikli ve farklı olmasının önemli olduğu ortaya çıkmıştır. Osterman'ın (2010) araştırması incelendiğinde öğretmelerden olumlu öğrenme ortamı oluşturabilmesi ve etkili sınıf yönetimi kurabilmesinin beklendiği görülmüştür. Araştırmalar incelendiğinde sınıf içerisinde farklı yöntemler kullanabilmesi (Marks, 2000), bireysel farklılıkları göz önüne alması (Yıldırım, Ünal ve Çelik, 2011), dersi eğlenceli olarak sunması (Çakmak ve Aktan, 2016), ders süresini ve sınıf içi davranış kontrolünü sağlaması (Can, 2004) gibi özelliklerin öğrenme- öğretme faaliyetlerini kapsadığı anlaşılmıştır (Karakelle, 2005). Özkan ve Arslantaş'ın (2013) araştırmasında öğretmenin s1nıfta yapıcı ve eğitsel bir disiplin sağlayabilmesi ve yeni yöntem ve teknikler uygulayabilmesini öğretmen nitelikleri açısından ilk sıralarda bulunması gerektiği ortaya çıkmıştır.

Eğitim-öğretim sisteminde nitelikli bir eğitimci olabilmek için iletişim sürecini çok iyi kullanmak gerekmektedir. Çünkü eğitim bir etkileşim sürecidir. İletişim ise bu etkileşimin önemli bir yönünü oluşturmaktadır. Araştırma bulguları analiz edildiğinde, öğretmenin kullandığı iletişim biçiminin öğrenciler tarafından dile getirildiği görülmüştür. Öğretmenlerin olumsuz yaklaşımları karşısında katılımcıların okula aidiyet duygusunun azaldığı, olumlu yaklaşımları karşısında ise fazlalaştığı anlaşılmıştır. Katılımcılardan edinilen veriler doğrultusunda iletişim biçimi ana teması ve 
ona bağlı olarak olumlu yaklaşım ve olumsuz yaklaşım alt temaları oluşturulmuştur. Katılımcılara göre öğretmenlerin dostça davranmaları, öğrenciye karşı samimi ve güler yüzlü olmaları, nazik ve kibar konuşmaları okula bağlanmaları açısından gerekli yaklaşımlardır. Bu sebeple samimiyet ve güler yüz gösterme, eşitlik belirten tutum, saygil, nazik gibi değerlere dayalı konuşma biçimi kodları olumlu yaklaşım alt teması altında birleştirilmiş, katılımcıların görüşleri ile desteklenmiştir. Öğrenciyi azarlama, onlara hakaret etme, bağırma, eşit muamele etmeme, kendi öğrencilik dönemiyle öğrencilerin yaşamını sürekli olarak kıyaslaması gibi yaklaşımlar katılımc1ların şikâyet ettiği olumsuz yaklaşımlar olarak kategorize edilmiş, hakaret ve şiddet, öğrenciler arasında ayrımcılık, kuşaklar arası kıyaslama kodu ile kavramsallaştırılmıştır. Yapılan araştırmalar incelendiğinde öğretmenlerin iletişim biçimlerinin öğrencilerin eğitim öğretim yaşamında farklılık yaratan en önemli etkenlerden biri olduğu anlaşılmıştır (Can, 2004; Cauley, Charfin ve Certo, 2001; Cothran ve Ennis, 2000; Çakmak ve Aktan, 2016; Erden vd, 2014; Savi, 2011; Şen ve Erişen, 2002).

Araştırmanın diğer bir nicel sonucu incelendiğinde, öğrencilerin okula aidiyet duyguları ile öğrenci-ebeveyn ilişkisi arasında anlamlı ve pozitif bir ilişki olduğu ve ebeveyn-öğrenci ilişkisinin, öğrencideki okula aidiyet duygusuna olumlu etki ettiği anlaşılmıştır. Ortaya çıkan bu sonuç dikkate alınarak öğrencilerle görüşmeler yapılmış, görüşmelerde katılımcılara ailelerin davranışları ile ilgili algıları ve deneyimleri sorulmuştur. Bu sorulara verilen cevaplar üzerinden ebeveynlerin hangi tutumu ve davranışlarının öğrencilerdeki okula aidiyet duygusunu etkilediğine dair öğrenci görüşleri incelenmiştir. Ebeveynler çocuklarının okul yaşamı boyunca başarılı olmasını istemekte ve bu beklentilerinin gerçekleşmesine yönelik çocuklarına karşı çeşitli disiplin yöntemleri ve denetim biçimleri sergilemektedirler. Yapılan görüşmeler sonucunda akademik başarı konusunda alg1lanan bu davranış kontrolü biçimlerinin katılımcılar tarafından dile getirildiği görülmüş ve davranış kontrolü ana teması belirlenmiştir.

Analizlerde öğrencilerin ifade ettiği davranış kontrolü biçimlerinin bir kısmının baskı olarak; bir kısmının ise destek olarak algılandığı fark edilmiş ve akademik başarı baskısı ile akademik başarı desteği alt temaları oluşturulmuştur. Akademik başarı baskısı bazı ebeveynlerin çocukların daha iyi eğitim alabilmesi için bilinçli olarak ya da bilinçsizce yaptığı davranışlar ve uyguladığı yöntemler sonucunda ortaya çıkmaktadır (Kapıkıran, 
2016). Öğrencilerin ifadelerine bağlı olarak oluşturulan akademik başarı baskısı alt tema'sına dair ifadeler dış kontrol odağı, aşırı beklenti, yoğun ilgi, olumsuz iletişim biçimi kodlarına dönüşmüştür. Bronstein, Ginsburg ve Henrera, (2005) tarafından yapılan araştırmada ailelerin dışsal kontrolü ve sürekli uyarma ve hatırlatma yapmalarının çocuklar tarafından olumsuz davranışlar olarak nitelendirildiği anlaşılmıştır. Ayrıca başarıya dair aşırı beklenti öğrencilerin eğitime dair sorumluluklarından kaçmasına sebep olmaktadır (Dam, 2008). Bu davranış biçiminin, çocukların motivasyonlarını düşürdüğü ve başarılarını olumsuz etkilediği görülmüştür. Yine yapılan birçok araştırmada aileleri tarafından başarı baskısını hisseden çocuklarda akademik başarının düşük olduğu anlaşılmıştır (Campbell ve Verna, 2007).

Öğrencilerle yapılan görüşmelerde, akademik başarı için yapılması gereken etkinliklerin, yerine getirilmesi gereken yükümlülüklerin ebeveynler tarafından merak edilmesinin ve takip edilmesinin olağan bir durum olarak karşılandığı görülmüştür. Analizler sonucunda görülmektedir ki katılımcılar, akademik başarının yükselmesine yönelik ebeveynlerin sergiledikleri birçok davranışı olumlu olarak niteleyip akademik başarı desteği destek olarak değerlendirmişlerdir. Öğrencilerin destek olarak algıladığı ifadeler incelendiğinde karşımıza iç kontrol odağı kurmayı isteme, yaşamlarında sosyal etkinliklere yer verme, duygusal destek ve anlayış, etkili iletişim biçimi ve sınırlı ilgi beklentisi çıkmıştır. Literatür incelendiğinde ebeveynlerin başarı baskısı ile ergenlerin başarı güdüsü arasında olumsuz, başarı destekleri ile olumlu yönde ilişki saptanmıştır. Çocuklarıyla samimi ilişkiler kuran, onlara güvenen ve serbest alan bırakabilen ailelerin verdiği akademik desteğin öğrenciyi olumlu olarak etkilediği görülmüştür (Bronstein ve diğ., 2005; Goodall ve Vorhaus, 2011; Gonzalez-DeHass, Willems ve Holbein, 2005; Kapıkıran ve Özgüngör, 2009; Keçeli-Kayısılı, 2008). Bu durum, araştırmanın sonucunun önceki çalışmaların sonuçlarıyla paralellik gösterdiğini ortaya koymuştur. Tüm bu tartışma ve yorumlardan hareketle, araştırmanın nicel verileri ile elde edilen sonuçların nitel sonuçlarla açıklık kazandığı, birbiriyle örtüştüğü dolaysıyla karma desen araştırmanın doğası ile uyumlu olduğu ileri sürülebilir.

Elde edilen nicel ve nitel bulgulara dayanarak bazı öneriler getirilebilir. Öncelikle öğrencilerin okula aidiyet duygularında aile, akran ilişkileri ve 
öğretmen değişkenlerinin önemi göz önüne alınmalıdır. Bu çerçevede, ailelerin çocuklarının okul süreçlerine dahil olurken daha sağlıklı bir iletişim biçimi kurmalarının, ilgilenme ile baskı kurma arasındaki farkı göz önüne almalarının öneli olduğu düşünülmektedir. Ayrıca araştırmadaki öğrenci grubunun ergenlik döneminde olduğundan ve bu dönemde akran ilişkilerinin öneminden hareketle, okulda öğrencilerin akranları ile olumlu bağlar kurabilecekleri faaliyetler oluşturulmasının gerekli olduğu ileri sürülebilir. Öte yandan öğretmenlerin, öğrencilerin okula dair aidiyet duygularında onlarla daha sağlıklı ilişkiler kurmalarının son derece önemli olduğu görülmektedir. Tüm bu değişkenler içinde okul psikolojik danışmanlarının da konsültasyon hizmetleri çerçevesinde veliler, okul idaresi ve öğretmenlerle işbirliği içinde yürüteceği çalışmaların öğrencilerin okula aidiyet duygularında olumlu etkiler yaratacağı söylenebilir. Son olarak okula aidiyeti etkileyen değişkenlerin farklı yöntemlerle araştırılmasının alanı zenginleştireceği düşünülmektedir. 


\title{
EXTENDED ABSTRACT
}

\section{A Mixed Study on High School Students' Sense of Belonging to School and Social Well-Being}

\author{
Durmuş Ümmet - Selçuk Doğan - Hatice Pınar Kemahlı \\ Marmara University - University of Florida - Düzce University
}

Students' academic achievements, fulfillment of their duties in all areas of development and, more broadly, the achievement of educational objectives are closely related to the sense of belonging that students feel about the school. The sense of belonging to the school is a concept that people are more focused on recently (Alkan, 2016). The sense of belonging to the school refers to the personal feelings of the students about how much approval they have from other people in the school, how much they are respected, how much they are included in the activities and supported. In this context, belonging to school is handled in relation to academic achievement and performance, motivation and self-efficacy (Goodenow and Grady, 1993; Roeser, Midgley and Urdan, 1996). Although there is sufficient research about which variables belonging to the school affects, there is not enough study indicating which variables affect the sense of belonging to the school. From this point forth, as a result of field study, the concept of "social well-being has occurred. Social well-being is divided into five dimensions: 1 ) a sense of belonging to the school, 2) the relationship of students with their families, 3) family support, 4) the relationship of students with their peers and 5) the relationship of the students with their teachers. Definitions for each dimension are briefly given below.

The main purpose of the survey to analyze the dimensions of social well-being of students occur in age group of 15 and uncover the extent of these dimensions on the sense of belonging to the school. For this purpose, the following sub-goals have been determined.

1) Are there any significant relationships between the social wellbeing of students and their sense of belonging to the school?

2) What are the experiences and perceptions of students about social well-being and school belonging? 
3) Do the quantitative findings of the study and their qualitative findings match?

This study is designed according to the sequential exploratory model of mixed methods research. In the quantitative part of the study, the relational screening model, which is a sub-type of the general survey model, has been used. In the second phase of the study, which is qualitative section, detailed data and in-depth analyzes are needed for the answers to the research questions. For this reason, the phenomonological model which is suitable for the studies aiming to reveal the experiences, perceptions and meanings of individuals related to a phenomenon has been applied.

For PISA 2015 Turkey, target population of students in the age group of 15 has been taken as 1,324,089, but 925366 students is considered as accessible population. The study was carried out with the participation of 5895 students (2937 girls and 2958 boys) from 187 schools in 61 cities in Turkey as computer based. In the qualitative part of the study, 12 students were selected out of the students in the age group of 15 by the maximum variation sampling method, which is one of the purposeful sampling methods, in order to detail, interpret and analyze the data in detail collected quantitatively.

In the quantitative part of the study, collection of data is based on the PISA 2015 study by the OECD in 2015. In PISA 2015, data were collected from the students by using 4-point Likert scale to learn their feelings about their social ties, their aloneness and their belonging to the school community. The collected data are combined under the concept of social wellbeing and discussed in five different dimensions: the relationship of the students with their families, the support of the family, the relationship of the students with their peers, the relationship between the students and their teachers, the sense of belonging to the school. Multi-level confirmatory factor analysis was used to test the construct validity of the dimensions. The composite reliability coefficient was calculated for reliability. Qualitative data were collected through "semi-structured interviews" method, one of the interview methods for qualitative study. Phenomenological data analysis was taken into consideration in the analysis of the qualitative data. 
It was found that there was a significant positive relationship between the feelings of belonging to school together with social well-being and family and teacher relations. On the other hand, it was found out that there was relationship between the students' sense of belonging to school together with social well-being and the social support of family . According to the results of regression analysis, family relations and teacher relations dimensions of social well-being have a statistically significant effect on the attitudes of students. However, the effects of family support and peer relations dimensions of social well-being on school belongings are statistically insignificant. All sub-dimensions together account for about $1 \%$ of the sense of belonging to school points.

In order to investigate the findings of the quantitative stage in which the secondary analysis of PISA data was performed, and to reveal the specific results, the qualitative phase was started. As a result of the analysis of the data collected from the participants in the study group, personal counselling (psychological support and social support codes), educational process (methods and techniques and classroom management codes), communication style (positive approach and negative approach codes), behavioral control (academic achievement stress and academic success support codes) main themes have been obtained. It is observed that students often want people around them to understand them, expect their teachers to communicate with them more healthily and expect them to teach their lessons more functionally in the class, and that they want their parents to trust them without causing academic parental pressure on them.

In order to evaluate the findings of the quantitative stage in which the secondary analysis of PISA data was performed, and to reveal the specific results, the qualitative phase was started. The quantitative and qualitative findings obtained are in line with the results of previous studies. Based on all these discussions and interpretations, it can be alleged that the results obtained by the quantitative data of the research are clarified by the qualitative results, they match each other, hence compatible with mixed methods research. Based on the findings, some suggestions can be made. First of all, the importance of family and peer relations and teacher variables should be taken into consideration. In all these variables, it can be said that 
the studies to be carried out by the school psychological counselors in cooperation with parents, the school administration and the teachers in the frame of the consultation services will have positive effects on the students' sense of belonging to the school. Finally, it is thought that researching variables affecting school belonging with different methods will enrich the field.

\section{Kaynakça / References}

Akın, A. (2008). Psikolojik iyi olma ölçekleri (PİOÖ): Geçerlik ve güvenirlik çalışması. Kuram ve Uygulamada Ĕ̆itim Bilimleri, 8(3), 721-750.

Alkan, N. (2016). Psychological sense of university membership: An adaptation study of the PSSM scale for Turkish university students. The Journal of Psychology 150(4), 431-449.

Altunçekiç, A., Erden, A., ve Aytaç, T. (2014). Orta öğretïm kademesïnde öğretmen-öğrenci ilişskilerïnin değerlendïrilmesï: KKTC örneğï. Kastamonu Ĕ̆itim Dergisi, 22(2), 761-782.

Baumeister, R. F. ve Leary, M.R. (1995). The need to belong: Desire for interpersonal attachments as a fundamental human motivation. Psychological Bulletin,117(3), 497-529.

Bollmer, J. M., Milich, R., Harris, M. J., ve Maras, M. A. (2005). A friend in need the role of friendship quality as a protective factor in peer victimization and bullying. Journal of Interpersonal Violence, 20(6), 701-712.

Borgonovi, F. ve Pal, J. (2016). A Framework for the analysis of student wellbeing in the PISA 2015 Study. OECD Education Working Papers, No. 140, OECD Publishing, Paris.

Bronstein, P., Ginsburg, G. S. ve Herrera, I. S. (2005). Parental predictors of motivational orientation in early adolescence: A longitudinal study. Journal of Youth and Adolescence, 34(6), 559-575.

Büyüköztürk, Ş., Çakmak, E. K., Akgün, Ö. E., Karadeniz, Ş., ve Demirel, F. (2008). Bilimsel araştırma yöntemleri. Ankara: Pegem Akademi.

Campbell, J. R., ve Verna, M. A. (2007). Effective parental influence: Academic home climate linked to children's achievement. Educational Research and Evaluation, 13(6), 501-519. 
Can, N.. (2004/1). Öğretmenlerin geliştirilmesi ve etkili öğretmen davranışları. Sosyal Bilimler Enstitüsü Dergisi, 16,103-119.

Cauley, K.M.. Charfin, C. ve Certo, J. (2001). Students' Perspectives on Their High School Experience. Metropolitan Educational Research Consortium.Erişim:https://scholarscompass.vcu.edu/cgi/viewcontent.cgi?referer=https://scholar.google.com/\&httpsredir=1\&article=1048\&context=merc_pubs. (25.11.2018 tarihinde erişilmiştir)

Cerit, Y. (2008). Öğretmen kavramı ile ilgilï metaforlara ilişsiin öğrencï, öğretmen ve yöneticilerïn görüşleri. Journal of Turkish Educational Sciences, 6(4), 693-712.

Chen, J. J. L. (2005). Relation of academic support from parents, teachers, and peers to Hong Kong adolescents' academic achievement: The mediating role of academic engagement. Genetic, Social, and General Psychology Monographs, 131(2), 77-127.

Clemson, D., ve Craft, A. (1981). The 'Good' or the 'Effective' teacher?. Journal of In-Service Education, 7(2), 135-136.

Cothran, D. ve Ennis, C. (2000). Building bridges to student engagement. Communicating respect and care for student in urban high school. Journal of Research And Development in Education. 33(2), 106-117.

Creswell, J. W. (2012). Educational research: Planning, conducting and evaluating quantitative and qualitative research (4th Ed.). USA: Pearson.

Cüceloğlu, D. (2001). Yeniden insan insana. İstanbul: Remzi Kitabevi

Çakmak, V. ve Aktan, E. (2016). Öğretmen öğrencï iletişïmïnïn çeşittlï değïskenlere göre incelenmesï. Electronic Journal of Social Sciences, 15(56). 83-97.

Dam, H. (2008). Öğrencinin okul başarısında aile faktörü. Hitit Üniversitesi İlahiyat Fakültesi Dergisi, 7(14), 75-99.

Decker, D. M., Dona, D. P., ve Christenson, S. L. (2007). Behaviorally atrisk African American students: the importance of student-teacher relationships for student outcomes. Journal of School Psychology, 45, 83-109.

Demir, İ. (2009).Gençlerin kimlik statülerinin kültürel karşılaştırması: İstanbul-Nusaybin örneği. Çocuk ve Gençlik Ruh Să̆gl̆ğı Dergisi, 16 (3), 129-136. 
Diener, E. (2001). Subjective well-being: The science of happiness and a propos al for a national Index. American Psychologist, 55-1(17), 3443.

Dilekmen, M. (2008). Etkili eğitim için etkili öğretmenlik. Atatürk Üniversitesi Sosyal Bilimler Enstitüsü Dergisi, 12(2), 213-221.

Dilmaç, B. ve Seki, T. (2015).Ergenlerin Sahip Oldukları Değerler ile Öznel İyi Oluş ve Sosyal Görünüş Kaygı Düzeyleri Arasındaki Yordayıcı İlişkiler: Bir Model Önerisi. Eğitim ve Bilim Dergisi, 40 (179), 57-67

Erden, M., Akman,Y. (1995). Eğitim psikolojisi gelişim-öğrenme-öğretme. Arkadaş Yayınevi: Ankara.

Eryılmaz, A. (2011). Ergen öznel ìi oluşu ile olumlu gelecek beklentisi arasındaki ilişkinin incelenmesi. Düşünen Adam Psikiyatri ve Nörolojik Bilimler Dergisi, 24, 209-215.

Eryılmaz, A. (2013). Ergenlerin öznel iyi oluşlarıyla aile ortamları arasındaki ilişki. Aile Toplum ve Eğitim-Kültür ve Araştırma Dergisi;, 12(24), 93-101.

Eryılmaz, A. ve Aypay, A. (2011). Lise öğrencilerinde derse katılmaya motive olma ile yaşam amaçları belirleme arasındaki ilişkiler. Ahi Evran Üniversitesi Ĕ̆itim Fakültesi Dergisi, 12(3), 149-158.

Fan, F. A. (2012). Teacher: students' interpersonal relationships and students' academic achievements in social studies. Teachers and Teaching: Theory and Practice, 18(4), 483-490.

Fidan, N., Duban, N., Yüksel, A., Kasapoğlu, K., ve Yamaç, A. (2013). Sınıf öğretmeni adaylarının gözüyle öğretmen eğitimcilerinin özellikleri. Kuramsal Ĕ̆itim Bilim Dergisi, 6(1), 136-159.

Finn, J. D. (1989). Withdrawing from school. Review of Educational Research, 59(2), 117- 142.

Goodenow, C., ve Grady, K. E. (1993).The relationship of school belonging and friends' values to academic motivation among urban students. The Journal of Experimental Education, 62(1), 60-71.

Gokhale, A.A. (1995). Collaborative learning enhances critical thinking. Journal of Technology Education, 7(1), 22-30.

Gonzalez-DeHass, A. R., Willems, P. P., ve Holbein, M. F. D. (2005). Examining the relationship between parental involvement and student motivation. Educational psychology review, 17(2), 99-123. 
Goodall, J., ve Vorhaus, J. (2011). Review of best practice in parental engagement. Comprehensive literature review on best practice in engagement of parents. Erişim: https://assets.publishing.service.gov.uk/government/uploads/system/uploads/attachment_data/file/182507/DFERR156_Practitioner_Summary.pdf (25.11.2018 tarihinde erişilmiştir).

Gordon, T., ve Burch, N. (2003). Teacher effectiveness training: The program proven to help teachers bring out the best in students of all ages. New York, NY: Three Rivers Press.

Gottfried, A. E. (1990). Academic intrinsic motivation in young elementary school children. Journal of Educational Psychology, 82(3), 525538.

Helliwell, J. F. ve Putnam, R. D. (2004). The social context of well-being. Philosophical Transactions of the Royal Society B: Biological Studies, $359,1435-1446$.

Juvonen, J., (2006). Sense of belonging, social bonds, and school functioning. In: Alexander, P. A., ve Winne, P. (Eds.), Handbook of Educational Psychology, pp. 655-674. New York: Routledge.

Kapıkıran, Ş. (2016). Ebeveyn akademik başarı baskısı ve desteği ölçeğinin psikometrik değerlendirmeleri ve yapısal geçerlik: Ortaokul ve lise öğrencileri. Ege Ĕ̆itim Dergisi, 17(1), 62-83.

Kapıkıran, Ş. ve Özgüngör, S. (2009). Ergenlerin sosyal destek düzeylerinin akademik başarı ve güdülenme düzeyi ile ilişkileri. Çocuk ve Gençlik Ruh Sağhlğ̆ Dergisi, 16(1), 21-30.

Karakelle, S. (2005). Öğretmenlerin etkili öğretmen tanımlarının etkili öğretmenlik boyutlarına göre incelenmesi. Ĕ̈itim ve Bilim, 30(135),110.

Keçeli-Kaysılı, B. (2008). Akademik başarının arttırılmasında aile katılımı. Ankara Üniversitesi Ĕ̆itim Bilimleri Fakültesi Özel Ĕ̆itim Dergisi. 9(1), 69-83.

Marks, H.(2000). Student engagement in instructional activity: Patterns in the elementary, middle and high school years. American Educational Research Journal, 37(1), 153-184.

Muthén, L. K., ve Muthén, B. O. (1998-2012). Mplus User's Guide (7th Ed.). Los Angeles, CA: Muthén ve Muthén. OECD. (2015). How's life? 2015: Measuring well-being. Paris: OECD Publishing. http://dx.doi.org/10.1787/how_life-2015-en. 
Osterman, K. F. (2010). Teacher practice and students' sense of belonging. In T. Lovat, R. Toomey, ve N. Clement (Eds.), International Research Handbook on Values Education and Student Wellbeing (pp. 239-260). Dordrecht, The Netherlands: Springer.

Pollard, E.L. ve Lee, P.D. (2003). Child well-being: A systematic review of the literature. Social Indicators Research, 61(1), 59-78.

Rath, T., Harter, J. ve Harter, J.K. (2010). Wellbeing: The five essential elements. New York: Gallup Press.

Raykov, T. (2004). Behavioral scale reliability and measurement invariance evaluation using latent variable modeling. Behavior Therapy, 35, 299-331.

Roeser, R.,W., Midgley, C., ve Urdan, T., C. (1996). Perceptions of the school psychological environment and early adolescents' psychological and behavioral functioning in school: The mediating role of goals and belonging. Journal of Educational Psychology, 88(3), 40842.

Rutkowksi, L., von Davier, M., ve Rutkowski, D. (2014). Handbook of international large-scale assessment: Background, technical issues, and methods of data analysis. USA: CRC Press.

Sarıcaoğlu, H. ve Arslan, C. (2013). Üniversite öğrencilerinin psikolojik iyi olma düzeylerinin kişilik özellikleri ve öz-anlayış açısından incelenmesi. Kuram ve Uygulamada Eğitim Bilimleri, 13(4), 2087-2104.

Savi, F. (2011). Çocuk ve ergenler için okula bağlanma ölçeği: Geçerlik ve güvenirlik çalışması. Illköğretim Online, 10(1), 80-90.

St-Amand, J., Girard, S., ve Smith, J. (2017, Summer). Sense of Belonging at School: Defining Attributes, Determinants, and Sustaining Strategies. IAFOR Journal of Education, 5(2),105-119.

Şen, H. Ş., ve Erişen, Y. (2002). Öğretmen yetiştiren kurumlarda öğretim elemanlarının etkili öğretmenlik özellikleri. Gazi Üniversitesi Gazi Ĕ̆itim Fakültesi Dergisi, 22(1), 99-116.

Özdemir, S. ve Sağkal, S.A. (2016).Ergenler için kısa okulda öznel iyi oluş ölçeği'nin türkçe'ye uyarlanması: Geçerlik ve güvenirlik çalışması. Ege Ĕ̆itim Dergisi,17(2), 333-350.

Özkan, M., ve Arslantaş, H. I. (2013). Etkili öğretmen özellikleri üzerine sıralama yöntemiyle bir ölçekleme çalışması. Trakya University Journal of Social Science, 15(1),311-330. 
Seligman, M. (2002). A Eudaimonic Approach to Psychological Well-Being. Journal of Hapiness Studies, 3(3), 34-45.

Şimşek H. ve Yıldırım A. (2013). Sosyal bilimlerde nitel araştırma yöntemleri. Ankara: Seçkin Yayınları

Şirin, A. ve Ulaş, E. (2015). Ortaokul Öğrencilerinin Öznel İyi Oluş Düzeyleri İle Karakter Eğitimi Uygulamaları Arasındaki İlişkinin İncelenmesi. Değerler Ĕ̆itimi Dergisi, 12(30), 279-307.

Taş, U. E., Arıcı, Ö., Ozarkan, H. B., ve Özgürlük, B. (2016). Uluslararası öğrenci değerlendirme programı: PISA 2015 ulusal raporu. Ankara: Milli Eğitim Bakanlığı Ölçme, Değerlendirme ve Sınav Hizmetleri Genel Müdürlüğü.

Woolfolk, A. E. (1990), Educational psychology. 9th edn., Allyn ve Bacon, Boston, MA.

Yaycı, L. (2016). Lise öğrencilerinde aileden algılanan sosyal destek ile de-

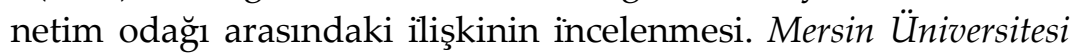
Eğitim Fakültesi Dergisi, 12(3), 829-843.

Yıldırım, A., Ünal, A., ve Çelik, M. (2011). Öğretmen kavramına ilişkin öğretmen, yönetici ve müfettiş algılarının analizi. Uluslararası İnsan Bilimleri Dergisi, 8(2), 92-109.

Yıldırım, İ. (2006). Akademik başarının yordayıcısı olarak gündelik sıkıntılar ve sosyal destek. Hacettepe Üniversitesi Ĕ̆itim Fakültesi Dergisi, 30(30) 258-267.

\section{Kaynakça Bilgisi / Citation Information}

Ümmet, D., Doğan, S. ve Kemahlı, H. P. (2019). Lise öğrencilerinin okula aidiyet duyguları ve sosyal iyi oluşları üzerine karma bir araştırma. OPUS-Uluslararası Toplum Araştırmaları Dergisi , 10(17), 1625-1663. DOI: $10.26466 /$ opus.517176 